www.jcmtjournal.com

\title{
Expression and regulation of aldehyde dehydrogenases in prostate cancer
}

\author{
Ali I. M. Ibrahim ${ }^{1,2}$, Maria Sadiq ${ }^{1}$, Fiona M. Frame ${ }^{3}$, Norman J. Maitland ${ }^{3}$, Klaus Pors ${ }^{1}$ \\ ${ }^{I}$ Institute of Cancer Therapeutics, School of Pharmacy and Medical Sciences, Faculty of Life Sciences, University of Bradford, West Yorkshire BD7 1DP, UK. \\ ${ }^{2}$ Department of Pharmacy, Al-Zaytoonah University of Jordan, Amman 11733, Jordan. \\ ${ }^{3}$ Cancer Research Unit, Department of Biology, University of York, Heslington, North Yorkshire YO10 5DD, UK.
}

Correspondence to: Dr. Klaus Pors, Institute of Cancer Therapeutics, School of Pharmacy and Medical Sciences, Faculty of Life Sciences, University of Bradford, West Yorkshire BD7 1DP, UK. E-mail: k.pors1@bradford.ac.uk

How to cite this article: Ibrahim AIM, Sadiq M, Frame FM, Maitland NJ, Pors K. Expression and regulation of aldehyde dehydrogenases in prostate cancer. J Cancer Metastasis Treat 2018;4:1-17.

Article history:

Received: 3 Feb 2018

First Decision: 24 Feb 2018

Revised: 9 Apr 2018

Accepted: 14 Jul 2018

Published: 21 Aug 2018

Key words:

Aldehyde dehydrogenase,

retinoic acid,

prostate cancer,

castration-resistant prostate cancer,

cancer stem cells,

multidrug resistance

\section{ABSTRACT}

The functional role of aldehyde dehydrogenases (ALDHs) in prostate cancer remains an area of some controversy. Many studies have used high ALDH functional activity to isolate putative cancer stem cells with tumour-initiating and propagating properties, while evidence is also emerging about the involvement of specific isoforms in migration, invasiveness and metastasis. Identification of specific ALDH isoforms, which contribute to both drug resistance and aggressiveness of the disease remains a challenge within the complex heterogeneity of prostate cancer. The purpose of this perspective is to dissect functional roles for ALDH in the tumour microenvironment and to evaluate the potential of the ALDH gene family as biomarkers and/or targets for therapeutic intervention.

\section{INTRODUCTION}

Prostate cancer $(\mathrm{PCa})$ is the most common cancer affecting men in the developed world. In the UK alone, over 47,000 new cases are diagnosed and more than 11,000 cancer related deaths are registered every year (Prostate Cancer UK, 2016). PCa is often present in the absence of apparent symptoms for many years, and so is considered to be slow-growing, however this is not true for all PCa's. Whilst the underlying cause of $\mathrm{PCa}$ is not fully understood, the initial stages of PCa frequently depend on androgens for cellular proliferation. If radiotherapy or radical prostatectomy cannot be used to eradicate or remove the tumour, then it is effectively treated by androgen deprivation therapy (ADT) ${ }^{[1,2]}$, especially if the tumour has escaped the capsule. However, the tumour invariably relapses in most patients after ADT, leading to an aggressive form of PCa known as castration-

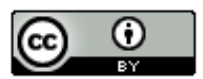

This is an open access article licensed under the terms of Creative Commons Attribution 4.0 International License (https://creativecommons.org/licenses/by/4.0/), which permits unrestricted use, distribution, and reproduction in any medium, as long as the original author is credited and the new creations are licensed under the identical terms.

For reprints contact: service@oaepublish.com

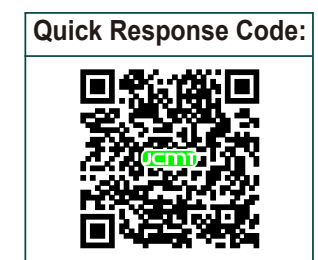


Table 1: Tissue distribution, subcellular distribution and substrates of human aldehyde dehydrogenases

\begin{tabular}{|c|c|c|c|}
\hline ALDH & Tissue distribution (main organs) & Subcellular localisation* & Substrate* \\
\hline $1 \mathrm{~A} 1$ & Most tissues $^{[225]}$ & Cytosol & Retinal \\
\hline $1 \mathrm{~A} 2$ & Testis $^{[226]}$ & Cytosol & Retinal \\
\hline $1 \mathrm{A3}$ & Retina, salivary gland and stomach ${ }^{[87]}$ & Cytosol & Retinal \\
\hline 1B1 & Small intestine, liver and pancreas ${ }^{[227]}$ & Mitochondria & Retinal \& acetaldehyde \\
\hline 1L1 & Liver, kidneys and muscles ${ }^{[228]}$ & Cytosol & 10-formyltetrahydrofolate \\
\hline $1 \mathrm{~L} 2$ & Pancreas, heart and brain ${ }^{[229]}$ & Mitochondria & 10-formyltetrahydrofolate \\
\hline 2 & Most tissues ${ }^{[230]}$ & Mitochondria & Acetaldehyde \\
\hline $3 A 1$ & Stomach, lung and cornea ${ }^{[231]}$ & Cytosol, partially in nucleus & Aromatic \& aliphatic aldehydes \\
\hline $3 \mathrm{~A} 2$ & Liver $^{[231]}$ & Endoplasmic reticulum & Fatty aldehydes \\
\hline 3B1 & Lung, prostate and kidneys ${ }^{[231]}$ & Endoplasmic reticulum & Octanal \\
\hline 3B2 & Salivary gland and placenta ${ }^{[232]}$ & Endoplasmic reticulum & Unknown \\
\hline $4 \mathrm{~A} 1$ & Liver, kidney and placenta ${ }^{[26]}$ & Mitochondria & Glutamate- $\gamma$-semialdehyde \\
\hline $5 \mathrm{~A} 1$ & CNS, brain and blood ${ }^{[233]}$ & Mitochondria & Succinate semialdehyde \\
\hline $6 \mathrm{~A} 1$ & Liver, kidney and heart ${ }^{[26]}$ & Mitochondria & Malonate semialdehyde \\
\hline $7 A 1$ & Liver, kidney and heart ${ }^{[231]}$ & Cytosol & $\alpha$-amino adipic semialdehyde \\
\hline $8 \mathrm{~A} 1$ & Liver, kidney and brain ${ }^{[26]}$ & Cytosol & Retinal \\
\hline $9 \mathrm{~A} 1$ & Liver, kidney and muscle $e^{[231]}$ & Cytosol & $\gamma$-aminobutyraldehyde \\
\hline $16 \mathrm{~A} 1$ & Bone, heart, kidney and lung ${ }^{[231]}$ & Transmembrane protein & Unknown \\
\hline $18 \mathrm{~A} 1$ & Pancreas, ovary, testis and kidney ${ }^{[231]}$ & Mitochondria & Glutamic- $\gamma$-semialdehyde \\
\hline
\end{tabular}

${ }^{*}$ Adapted from references ${ }^{[26,32]}$

resistant prostate cancer (CRPC), which remains an untreatable disease $\mathrm{e}^{[1,3]}$.

The tumour microenvironment (TME) exerts a strong hold on tumour initiation, progression and metastasis ${ }^{[4]}$. TME is a general term encompassing a complex heterogeneous environment which includes inflammatory cells, blood vessels, extracellular matrix $^{[5]}$ and fibroblasts (stroma). In normal prostate homeostasis, a controlled interaction between nonepithelial components such as stroma and epithelial cells contributes to normal epithelial proliferation, differentiation and migration ${ }^{[5,6]}$. When prostate epithelial cells have acquired a malignant phenotype, this crosstalk between prostate epithelium and stromal cells is perturbed ${ }^{[6]}$. As a consequence, stromal cells play a critical role in activating cellular events within the TME that sustain and support cancer proliferation and metastasis ${ }^{[4,7]}$. Multiple studies of cell signalling associated with androgen ${ }^{[8]}$, Hedgehog ${ }^{[9]}$, fibroblast growth factor $(F G F)^{[10]}$, Src family kinase ${ }^{[11]}$, transforming growth factor- $\beta$ (TGF- $\left.\beta\right)^{[12]}$, Integrin $^{[13]}$ and Notch ${ }^{[14]}$ pathways, implicate the TME, however many such observations are derived using a mixture of both human and mouse models in which the TMEs are radically different. Accordingly more careful attention is required to evaluate the impact of the TME.

Within a tumour, the entire population of replicating cancer cells has been hypothesised to be derived from a small subpopulation of cancer stem cells (CSCs) or tumour initiating cells $(\mathrm{TICs})^{[15]}$. CSCs have the ability to both self-renew and to produce progenitor and differentiated cells, generating phenotypically diverse tumour cell populations ${ }^{[16]}$. The stem cell microenvironment (SCME) is a specific anatomic location (or "niche") where stem cells (SCs) are located, and the interplay between SCs and these niches can regulate the dynamic process of SCs' role in tissue generation, maintenance and repair ${ }^{[17]}$. Several factors affect SC regulation within the SCME, including the interactions of SC with each other, with differentiated cells, and with extracellular matrix components ${ }^{[18]}$. Dysfunction of a cellular process or signalling pathway within the SC niche could contribute to the evolution of a $\mathrm{CSC}^{[19]}$. Although the presence of this CSC niche could pose obstacles for the treatment of $\mathrm{PCa}$, it has also been proposed that the CSC niche also provides a potential target for biomarker and drug discovery ${ }^{[20-22]}$.

Aldehyde dehydrogenases (ALDH) have been exploited as selective markers for CSCs and have been assigned potential functional roles in differentiation, self-protection and expansion ${ }^{[23]}$. The ALDH superfamily consists of 19 genes with distinct chromosomal locations, which are found across 11 families and 4 subfamilies ${ }^{[23-25]}$. These enzymes have a varied tissue and organ distribution ${ }^{[26-28]}$ and are localised in the cytoplasm, mitochondria, nucleus, and endoplasmic reticulum ${ }^{[23,24]}$. ALDH isoforms show distinct substrate specificity ${ }^{[26,29,30]}$, and are $\mathrm{NAD}(\mathrm{P})+$ dependent [Table 1]. Their major role is the detoxification of endogenous and exogenous molecules, via oxidation of aldehyde substrates to 
their corresponding acids. This catalytic oxidation is a fine-tuned reaction evolved to protect cells from the harmful effects of highly reactive aldehydes and maintains cellular homeostasis ${ }^{[24,25,31]}$. Vital functions include protection of cells from oxidative stress (e.g., reactive oxygen species, ROS) and promotion of retinoic acid (RA) metabolism and signalling ${ }^{[32]}$.

Mutations and polymorphisms in ALDH genes lead to a loss-of-function that are associated with various human pathologies ${ }^{[33-39]}$, which supports their important biological function. Plentiful studies have described the expression of ALDHs in human tissues, however their expression profile and functional activity is poorly understood within the TME. As a consequence of high and abundant expression, ALDHs have been considered to be biomarkers of specific tumour types ${ }^{[40-45]}$. Human ALDHs are among the regulatory proteins that catalyse the retinoic acid (RA) pathway, which has been linked with "stemness" characteristics ${ }^{[45]}$. The ALDH1A subfamily members have also been identified in a wide-range of human CSCs, and their expression has been associated with poor prognosis in patients with several cancer types including $\mathrm{PCa}^{[46-54]}$

\section{ALDH EXPRESSION AND REGULATION IN PROSTATE CANCER}

The rate and frequency of $\mathrm{PCa}$ progression varies considerably between individuals, ranging from relatively slow (indolent, non-invasive) in some patients whilst in other cases the disease is more aggressive and results in rapid metastasis ${ }^{[55]}$. At present, $\mathrm{PCa}$ is diagnosed at first by monitoring levels of serum prostate-specific antigen (PSA) and digital rectal examination ${ }^{[55]}$. However there is a substantial overlap in PSA levels between patients with benign prostatic hyperplasia (BPH) and patients with $\mathrm{PCa}^{[55]}$. About $25 \%$ of cases with $\mathrm{PCa}$ display no increase in serum PSA levels and thus must be detected by other methods ${ }^{[55]}$, such as diagnostic needle biopsies and MRI scans. Furthermore, it is crucial to determine indolent from aggressive forms of PCa, to offer patients earlier diagnosis and better treatment options. This is neither currently possible nor routine. In this regard, more detailed, in-depth understanding of the correlation between ALDHs and $\mathrm{PCa}$ progression may provide alternative biomarkers for disease diagnosis and treatment.

As indicated above, a complex interplay of $\mathrm{PCa}$ with the surrounding stroma, androgen receptor (AR) signalling, epithelial-to-mesenchymal transition
(EMT) and other signalling pathways within the TME support progression of the disease. Stromal cells such as fibroblasts and myofibroblasts are involved in hormone signalling, contributing to stromal-epithelial interactions in the primary tumour setting ${ }^{[56-58]}$. For example both stromal and epithelial ALDH1 expression, measured using IHC, have been shown to be a potential biomarker for breast cancer ${ }^{[59]}$. The epithelial and stromal ALDH1 expression (detected in $43 \%$ and $69 \%$ of benign breast biopsies, respectively) was associated with a predicted increase in the risk of breast cancer. However, as with many earlier studies $^{[45]}$ on profiling ALDHs in clinical specimens, no information is available to ascertain which ALDH was overexpressed from the subfamily (ALDH1A1, 1A2, 1A3, 1B1, 1L1, 1L2).

In $\mathrm{PCa}$, several ALDH isoforms (1A1, 1A3, 3A1, 3A2, $4 A 1,7 A 1,9 A 1$ and $18 A 1$ ) have been found to be overexpressed ${ }^{[15,60-68]}$, but only a few isoforms appear to play critical roles in $\mathrm{PCa}$. In a recent proteomic study ${ }^{[69]}, A L D H 1 A 3$ expression was in part controlled via miR-187, as downregulation of this microRNA led to induction of ALDH1A3, while re-introduction decreased ALDH1A3 expression in PC-3, DU145 and LNCAP prostate cancer cells. Some ALDHs may also contribute to regulation of AR pathways, with implications for normal prostate development, prostate carcinogenesis and progression to androgen-independent disease ${ }^{[70-73]}$. AR is expressed in almost all primary PCas ${ }^{[74-76]}$ and the transition from a localised hormone-naïve to a castrationresistant phenotype is based on a complex interplay of signalling molecules attributed to aberrant AR signalling ${ }^{[73,77-79]}$. Raised PSA suggests that AR function is still active but abnormal in $\mathrm{CRPC}^{[80]}$, due to a number of different mechanisms including $A R$ amplification ${ }^{[81]}$, AR gain-of-function mutations ${ }^{[82]}$, intracrine androgen production ${ }^{[83]}$, elevated levels of AR cofactor that sensitises cancer cells to low levels of androgens ${ }^{[84]}$, ligand-independent activation of AR by growth factors and cytokines ${ }^{[85]}$ and constitutively active messenger ribonucleic acid (mRNA) spliced variants of $A R^{[86]}$. Consequently, $A R$ remains a critical factor in the progression of early-stage PCa to CRPC.

ALDH1A3 is androgen responsive in human epithelial LNCaP cells since its expression was 4 -fold higher after treatment with dihydrotestosterone (DHT), which indirectly affects both AR regulation and cell differentiation ${ }^{[59]}$. ALDH1A3 has also been correlated with $A R$ signalling pathway in primary $\mathrm{PCa}$ tissue where expression was consistent with luminal layer localisation $^{[65]}$. Significantly, the study also showed that knockdown of ALDH1A3 led to substantial 
reductions in proliferation rate and the invasive ability of PC-3 cells. However, the regulation of ALDH1A3 expression is likely to be multifactorial ${ }^{[87]}$.

Outside the ALDH1 family, strong association of ALDH3A1 with PCa progression has also been demonstrated in both immortalised cancer cell lines and tumour xenografts ${ }^{[61]}$. In clinical tissues ALDH3A1 was detected in intra-epithelial neoplasia, with elevated levels in carcinomas in the absence of expression in normal prostate glands. Finally, in comparison with the paired local carcinomas, ALDH3A1 was upregulated in both lymph node metastatic tumours and was detectable in bone metastatic PCa.

ALDH7A1, which has also been related to the stemness of $\mathrm{CSCS}^{[88]}$, is mainly localised in the cytosol, but it has also been found expressed to a lesser degree in the mitochondria and nucleus ${ }^{[32,45]}$. In addition to catalysing aldehyde metabolism, ALDH7A1 also plays a role in protecting tissues from the damaging effects of osmotic stress ${ }^{[89]}$ while mutation of the ALDH7A1 gene has been related to pyridoxinedependent epilepsy ${ }^{[90,91]}$. In cancer, ALDH7A1 is expressed in nodular melanoma (NM) ${ }^{[92]}$, ovarian ${ }^{[93]}$ and lung cancers ${ }^{[94]}$ while in PCa the isoform has been shown to be involved in intra-bone growth and induced bone metastasis ${ }^{[64]}$ as well as zoledronic acid resistance ${ }^{[95]}$. Gene expression profiling supports the involvement of ALDH7A1 in multiple molecular pathways related to the metastatic process in $\mathrm{PCa}^{[96]}$.

\section{EVIDENCE FOR EPIGENETIC CONTROL OF ALDHS}

PCa can be initiated by genetic or epigenetic alterations, including DNA methylation in the promoter region of genes, normally linked to transcriptional silencing ${ }^{[55]}$. Epigenetic changes including DNA methylation and histone modifications of tumour suppressor genes (TSGs) preferentially occur in the early stages of cancer progression ${ }^{[55]}$. The promoter region of ALDH1A2 in primary $\mathrm{PCa}$ specimens has been shown to be densely hypermethylated in comparison to normal prostate tissues ${ }^{[97]}$. This observation is supported by another study that showed a low/absent expression of ALDH1A2 in PCa in formalin-fixed paraffin embedded sections compared to elevated levels of expression in normal prostate tissue ${ }^{[98]}$. On this basis it was suggested that ALDH1A2 act as a TSG in PCa, and that its epigenetic regulation could differentiate normal prostate cells from malignancy. In contrast,
ALDH1A3 has been demonstrated to be an androgen responsive gene ${ }^{[67]}$ whose induction contributes to the conversion of retinol to RA with potential for supporting cellular proliferation ${ }^{[55]}$. Hypermethylation of the ALDH1A3 promoter region in clinical tissues has also been detected ${ }^{[99]}$, but this study used a relatively small sample size $(n=24)$ and did not distinguish between methylation of basal and luminal PCa cells. Although larger studies are required, it is possible that methylation of the promoter regions of ALDH1A2 and ALDH1A3 could be used as a marker for $\mathrm{PC}$ a detection ${ }^{[5]}$.

\section{ALDH EXPRESSION IN CSC MICROENVIRONMENT}

Growing evidence strongly supports initiation of $\mathrm{PCa}$ from CSCs residing within a basal nich ${ }^{[100-105]}$. In xenotransplantation experiments, less than 100 TICs are needed to generate a new tumour in mice and these cells exhibit a basal phenotype ${ }^{[106]}$. Furthermore, using human tissue biopsies the prostate SC markers CD44+, $\alpha 2 \beta 1$-integrinhigh and CD133+ have been used to identify and isolate prostate CSCs with selfrenewal capacity in vitro ${ }^{[100]}$. Additionally, there are other important markers that have been used to identify and isolate PCa SCs. ATP binding cassette $(A B C)$ transporters which are proteins that play a vital role in the efflux of drugs have also been used to enrich CSCs. However, CD44+, $\alpha 2 \beta 1$-integrin high and $C D 133+A B C$ transporters are also expressed in normal SCs ${ }^{[107,108]}$ which emphasises the need to employ at least two markers to avoid cross reacting populations of cells ${ }^{[107]}$. A growing body of evidence suggests that the functional activity of ALDHs can be used to identify and purify CSCs from e.g. breast ${ }^{[109]}$, ovary $^{[110]}$, lung ${ }^{[111]}$, colon ${ }^{[112]}$, pancreas ${ }^{[113]}$ and prostate cancer ${ }^{[114]}$. At present it is unclear if ALDH expression is significantly different between normal SCs and CSCs, hence more research is required to understand if any isoforms could be more predictive than e.g. $C D 44+, \alpha 2 \beta 1$-integrin high and CD133+ used as a PCa SC gene-expression signature ${ }^{[115]}$

ALDHs expressed in SCs are members of the ALDH1 family $(1 \mathrm{~A} 1,1 \mathrm{~A} 2,1 \mathrm{~A} 3,1 \mathrm{~L} 1,1 \mathrm{~L} 2), \mathrm{ALDH} 2, \mathrm{ALDH} 3 \mathrm{~A} 1$, ALDH4A1 and ALDH7A1, which have all been linked with various critical roles including chemo-protection, DNA damage and regulation of the cell cycle ${ }^{[24]}$. The Aldefluor assay has frequently been used to identify and isolate CSCs, but as this assay does not distinguish between different isoforms many studies suffer from a lack of knowledge of the contributing ALDHs to the stemness of the isolated subpopulations with tumourigenic properties. However, some 
studies have shown that e.g. the ALDH1A1 isoform positively correlates with the expression of CSC surface markers CD133 ${ }^{[116]}$ and $\mathrm{CD} 34^{[117]}$ with utility in characterising liver CSCs and leukaemia SCs, respectively. The association of ALDH3A1 has also been reported in $\mathrm{PCa}$ progression ${ }^{[61]}$. Stem cell-like cells from DU145 cells have elevated expression of ALDH3A1 compared to non-stem counterparts, and the stem cell-like population generated xenograft tumours with aggressive features ${ }^{[118]}$.

\section{ALDHS AND THE RETINOID SIGNALLING PATHWAY}

Retinoic acid (RA, all-trans retinoic acid (ATRA), tretinoin) the physiologically active metabolite of vitamin $\mathrm{A}$ (retinol) is a potent regulator of signalling pathways during embryonic development ${ }^{[119]}$. RA is necessary for adult tissue homeostasis and acts through nuclear retinoic acid receptors (RARs) ${ }^{[120]}$, with diverse immune modulatory roles ${ }^{[121,122]}$, role in spermatogonial differentiation ${ }^{[123]}$, and cancer ${ }^{[124-126]}$. RA is endogenously produced from retinol (vitamin A) in two subsequent metabolic steps [Figure 1]: the first step is the retinol oxidation to retinaldehyde, which is catalysed by several alcohol dehydrogenases (also known as retinol dehydrogenases $)^{[127,128]}$. The second step is the oxidation of retinaldehyde to retinoic acid, which is an irreversible step carried out by ALDHs (also known as retinal dehydrogenases) ${ }^{[129]}$. At least four ALDH isoforms, ALDH1A1, 1A2, 1A3 and 8A1, have been shown to be responsible for the oxidative formation of retinol to $\mathrm{RA}^{[128,130-132]}$. ALDH1A3 appears to be the most catalytically efficient enzyme for RA oxidation and has no apparent capacity to metabolise cis-retinal substrates ${ }^{[133]}$. The involvement of ALDHs in RA synthesis underpins their vital function in pathways associated with cell proliferation, differentiation and survival ${ }^{[8]]}$.

The synthesised RA binds to nuclear RAR and retinoid $X$ receptor $(R X R)$ forming a heterodimeric complex, which binds to RA response elements (RAREs), leading to downstream regulation of gene expression and cell differentiation events ${ }^{[134-137]}$. RA and 9-cis-RA (isotretinoin) bind to RARs, whereas only 9-cis-RA can bind to $R X R s^{[23]}$. In response to $\mathrm{RA}$ synthesis, cellular retinoic acid binding protein (CRABP) shuttles RA to the nucleus where it binds to the RAR/RXR heterodimer ${ }^{[138,139]}$. This subsequently results in the dissociation of co-repressors NCoR, SMRT and HDAC complex ${ }^{[140]}$ and allows coactivators such as SRC/p160 family, p300/CBP and CARM-1 to bind ${ }^{[141,142]}$. The chromatin structure is relaxed by the action of histone acetyltransferase (HAT) or methyltransferase activity ${ }^{[143]}$, facilitating the recruitment of transcriptional machinery which stimulates RA responsive gene transcription ${ }^{[144,145]}$.

The RA biosynthetic pathway is likely to be suppressed or activated depending on the local prostate microenvironment ${ }^{[146-148]}$. The effect of RA has been investigated in normal and malignant prostate tissues ${ }^{[129,149]}$. Differential expression of RA was demonstrated in normal prostate, $\mathrm{BPH}$, and prostate carcinoma tissues ${ }^{[129]}$. For example it was found that endogenous retinol levels were 2-fold elevated in $\mathrm{BPH}$ compared to normal and $\mathrm{PCa}$ tissue while RA levels were found 5-8 times lower in PCa tissue compared with the other two tissues. The authors speculated that the reason for this elevated level of retinol in $\mathrm{BPH}$ could reflect (1) a reduced activity of the dehydrogenase that metabolises retinol to retinal or (2) uptake from serum that metabolises retinol to retinal. A possible cause for the reduced level of RA in PCa could be a more rapid degradation of RA by cytochrome P450 enzymes ${ }^{[150]}$.

In addition, RA also has variable effects on $\mathrm{PCa}$ signalling pathways, either directly or indirectly by regulating certain transcriptional factors such as $\mathrm{NR} 2 \mathrm{~F} 1^{[151]}$ and RA receptor responder 1 (RARR1) ${ }^{[152]}$ since RA represses invasion and SC phenotype by induction of metastasis suppressors RARR1 and latexin $(\mathrm{LXN})$ in $\mathrm{PCa}^{[153]}$.

Retinoids are used as cancer treatment, in part due to their ability to induce differentiation and arrest proliferation. In the clinic, RA has been clinically investigated in $\mathrm{PCa}$ as single treatment ${ }^{[154]}$, or with other agents in attempts to produce synergistic effects $^{[155-157]}$. However, delivery of retinoids presents a challenge because of the rapid metabolism and the epigenetic alterations that can render cells retinoid resistant ${ }^{[158]}$. This poses new challenges rather than solutions. ALDH1A3 expression is regulated by many factors and is linked to many metabolic pathways including glycolysis and retinoid signalling, which has been recently reviewed ${ }^{[87]}$ and hence not further discussed here.

The relationship between AR and ALDH1A3 has been studied in both normal and tumour tissues, to understand the exact mechanism of their interaction, and its relationship to the role of ALDH1A3 as a marker of CSCs in several tumour types. In breast cancer, a potential link between ALDH1A3 expression and RA signalling contributed to an increase in the rate of cancer progression ${ }^{[159]}$. In human epidermal 


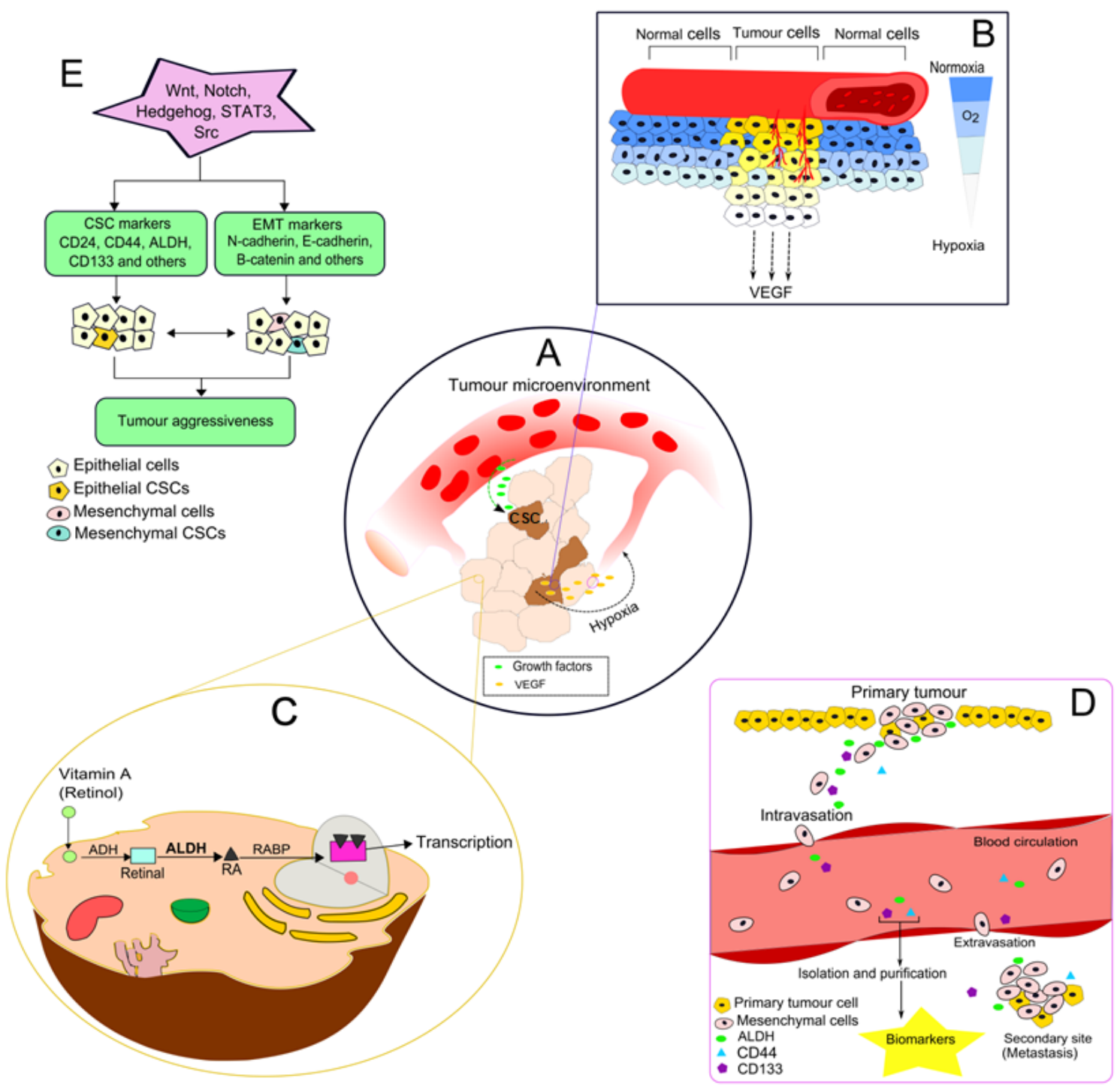

Figure 1: Aldehyde dehydrogenases (ALDHs) expression and function in the tumour microenvironment. ALDH expression in cancer stem cells (CSCs) and differentiated cells have been linked with several cellular processes including glycolysis/glucogenesis and amino acid metabolism, which are likely to be affected by the local microenvironment including impact by hypoxia (A, B). Various ALDH isoforms have been shown to be regulated by e.g. tumour suppressor genes, oncogenes and microRNAs, however a well-documented functional role is linked with the retinoic acid (RA) pathway resulting in transcriptional activation of a number of genes important in cell differentiation (C). High ALDH expression is frequently used as an endogenous marker that in combination with cell surface markers can be used to isolate CSCs (D). More research is required to understand how ALDH activity may contribute to signaling pathways, maintenance of CSCs and contribute to tumour aggresiveness $(D, E)$

keratinocytes, it has been shown that regulation of RA metabolism involved the transcriptional activation of only ALDH1A3 amongst a panel of ALDH genes ${ }^{[160]}$. ALDH1A3 activity induced by RA-regulated genes has been proposed to play a role in establishing a unique transcriptional profile that favours the CSC phenotype ${ }^{[161,162]}$. Conversely, a recent study revealed that ALDH1A1, 1A2 and $1 A 3$, were downregulated in the undifferentiated embryonal cancer Wilms' tumour 1 (WT1) resulting in inhibition of RA synthesis ${ }^{[163]}$.
Blum et al. ${ }^{[164]}$ investigated the regulation of both RA and ALDH1A3 in the urogenital sinus epithelium (UGE), which contains primitive foetal prostate cells. A number of the major regulators of the RA receptor, including ALDH1A3 were up-regulated in both primitive populations of adult and foetal prostate SCs, with 10-fold increased ALDH activity in adult prostate SCs compared to cell population (Sca-1Neg) with no regenerative potential. In addition, expression of CRABP, which transports RA into the nucleus to bind 
RA receptors was 47-fold up-regulated in the UGE, as confirmed by $\mathrm{qPCR}$ analysis, and may indicate the potential of these cells to differentiate. In the context of PCa, ALDH1A3 might play a significant role in the CSC niche of the TME, thereby contributing to a survival mechanism.

\section{THE CSC NICHE, SIGNALLING PATHWAYS AND POTENTIAL FOR THERAPEUTIC INTERVENTION}

Cancer cells acquire a more invasive and migratory phenotype through EMT ${ }^{[165-168]}$. Cell adhesion is reduced in early metastatic $\mathrm{PCa}$ by downregulation of expression of E-cadherin and $\beta$-catenin (characteristically expressed in normal epithelial cells ${ }^{[169]}$. In contrast, the expression of $\mathrm{N}$-cadherin (characteristically expressed in mesenchymal cells) is upregulated ${ }^{[170]}$. In clinical specimens there is lower E-cadherin and $\beta$-catenin expression and higher $\mathrm{N}$-cadherin expression in higher grade $\mathrm{PCa}$ compared to lower grade PCa ${ }^{[171-174]}$. However restoration of elevated $\mathrm{E}$-cadherin expression and $\beta$-catenin was seen in metastatic cells deposited in the bone ${ }^{[175]}$, implicating expression control rather than total E-cadherin gene loss.

The Wnt/ $\beta$-catenin signalling pathway plays a significant role in maintaining the stemness of $\mathrm{PCa}^{[176,177]}$. In radioresistant ALDH+ (identified by Aldefluor assay) prostate progenitor cells, activation of EMT and the $W n t / \beta$-catenin signalling pathways has been demonstrated. In this study, ALDH1A1 gene expression was regulated by the Wnt signalling pathway and correlated with simultaneous expression of $\beta$-catenin in whole prostate tumour specimens ${ }^{[178]}$. Encouragingly, inhibition of the Wnt pathway (by siRNA knockdown or the tankyrase inhibitor XAV939) resulted in reduced ALDH+ tumour progenitor population and radio-sensitisation of cancer cells ${ }^{[178]}$. The link between ALDH1A1 and $\beta$-catenin has also been demonstrated using spheroidal aggregates in a xenograft model comprised of ovarian cancer cells with stem cell characteristics ${ }^{[179]}$. In this study, $\beta$-catenin knockdown decreased ALDH1A1 expression, which subsequently led to inhibition of tumour growth and metastasis.

As described above, ALDH7A1 is highly expressed in primary $\mathrm{PCa}$ tissue ${ }^{[15,88]}$. ALDH7A1 knockdown decreased the stem/progenitor cell subpopulation in the human PCa cells and tumour migration ability in vitro $^{[88]}$. The activity was correlated with increased TGF- $\beta$ signalling, which strongly induced ALDH7A1 activity while the activity could be inhibited with a TGF- $\beta$ signalling antagonist ${ }^{[88]}$. Overexpression of the TGF- $\beta$ signalling pathway correlates with poor clinical outcomes in PCa. TGF- $\beta$ promotes tumour progression by stimulating the metastasis and angiogenesis ${ }^{[180]}$.

As with many other studies, investigation of ALDH+ cells isolated from both PCa cell lines and primary cells have shown self-renewal, colony forming capacity and tumourigenicity. ALDH expression correlated with CD44 and $\alpha 2 \beta 1$-integrin expression as well as phosphorylation of the transcription factor STAT3. Galiellalactone, a potent and specific inhibitor of STAT3 signalling, reduced ALDH1A1 expression and subpopulation of ALDH+ cells following treatment of DU145 PCa xenografts. This study highlighted the role of the STAT3 signalling pathway in putative prostate CSCs and further supports STAT3 as a potential therapeutic target ${ }^{[181]}$. In a separate study using primary tumour cells, STAT3 inhibition resulted in both cell death and CSC differentiation, resulting in a loss of both colony forming and tumour initiating capacity ${ }^{[182]}$.

\section{ALDH ASSOCIATED DRUG RESISTANCE IN THE TME}

A number of studies have linked ALDH expression with chemotherapy resistance, although the underlying mechanisms are not well understood. Whilst chemotherapy reduces the bulk of a tumour, it also enriches the previously described CSC population ${ }^{[183-185]}$ which are not susceptible to anti-mitotic drugs currently approved for clinical use. Although evidence is not available in $\mathrm{PCa}$, CSCs have been shown to be highly resistant to both radiotherapy and chemotherapies including temozolomide, gemcitabine, etoposide, carboplatin, paclitaxel, fluorouracil, mitoxantrone, daunorubicin and cyclophosphamide (CPA $)^{[186-200]}$, contributing to tumour recurrence and metastasis. There are several possible mechanisms for CSC resistance to cancer therapy. Firstly, CSCs are slow-proliferating cells in a quiescent state and thus resist drugs primarily designed to target rapidly dividing cells ${ }^{[201]}$. Secondly, CSCs resist irradiation because of increased activation of the DNA damage checkpoint response, as exemplified in a recent study of glioblastoma $\mathrm{CSCs}^{[202]}$. Thirdly, increased expression of $A B C$ transporters protects CSCs from high concentrations of drugs ${ }^{[203]}$, as demonstrated by removal of Hoechst stain in analysis of side populations ${ }^{[204,205]}$. Lastly, high ALDH expression is likely linked to metabolic and detoxifying mechanisms, supporting a role as chemoprotecting enzymes ${ }^{[201]}$. 
Early studies first demonstrated a chemo-resistant role for ALDHs in a CPA resistant L1210 leukaemia cell line ${ }^{[206]}$. This study showed that high levels of ALDH activity were found in L1210 cells and that treatment with disulfiram (ALDH inhibitor) reversed the resistance phenotype of the cells to CPA. A subsequent study confirmed the role of ALDHmediated CPA resistance in medulloblastoma ${ }^{[207]}$. Similar studies demonstrated that high ALDH activity indicates CPA resistance in cancer and $\mathrm{CSCs}^{[208]}$. Accordingly, inhibition of ALDH activity can in principle serve to sensitise CSCs to drugs such as $\mathrm{CPA}^{[209]}$. More specifically, ALDH1A1 and ALDH3A1 were both shown to inactivate CPA analogues ${ }^{[210,211]}$.

The sphere forming cells (a common property of CSCs), from the sarcoma cell line MG63 were significantly insensitive to doxorubicin and cisplatin treatment compared with monolayer adherent counterparts. The sarcosphere cells with high ALDH1 activity were proposed as candidate sarcoma $\mathrm{SCs}$, in which efficient drug detoxification is likely to have contributed to generation of a chemo-resistant CSC phenotype ${ }^{[191]}$. Furthermore, high ALDH expression in CSCs has shown chemo-resistance in both breast $\mathrm{CSCs}^{[190,212]}$ and head and neck squamous cell carcinoma (HNSCC) $\mathrm{SCs}^{[213]}$, where ALDH expression was associated with high Snail expression, a marker of EMT. Knockdown of Snail expression significantly decreased the expression of ALDH1 whilst blocking the tumorigenic abilities of CD44+ CD24- ALDH1+ cells ${ }^{[213]}$. Although many chemotherapeutic drugs are less effective in ALDHexpressing cancer cells, the underlying mechanisms are poorly understood. None of the drugs contain aldehyde functional groups that are direct substrates for biochemical reactions with ALDHs, but esterase activity has been shown for some of these enzymes, which potentially provides an ALDH mediated resistance mechanism for drugs such as the taxanes. Phase 1 metabolism resulting in short lived aldehydes as illustrated for CPA are direct substrates for ALDH detoxification, providing a potential resistance mechanism in ALDH+ expression cells including CSC population within the TME [Figure 2]. Drug resistance can be reversed by co-treatment with an ALDH inhibitor such as DEAB. For example, doxorubicin, paclitaxel and radiotherapy resistance in breast cancer cell lines has been reversed following treatment with DEAB or $\mathrm{RA}^{[190]}$.

\section{ALDH, HYPOXIA AND TME}

Hypoxia is not only a major feature of the tumour microenvironment but is also a potential contributor to the multidrug resistance (MDR) and enhanced tumourigenicity of $\mathrm{CSCs}^{[214]}$. Within the proposed hypoxic CSC niche, the cells are surrounded by an acidic microenvironment that activates a subset of metastasis promoting proteases such as MMPs and cathepsins ${ }^{[215]}$. As a consequence of poor angiogenesis and the inaccessible location, hypoxic cells are exposed to insufficient drug concentrations, which promote the survival of a drugresistant sub-population of cells. The lower oxygen tension increases resistance to radiotherapy and as discussed above, also enriches CSC niche within the TME. Hypoxia-activated prodrugs (HAPs) have been investigated for several decades and have shown considerable promise in combination with chemotherapy or radiotherapy, but no HAPs have yet been approved for clinical use. Unravelling the $\mathrm{PCa}$ microenvironment is likely to offer new insight and opportunities to molecularly stratify patients for treatment, based on their tumours' hypoxic signature, including analysis of enzymes with oxidase and/ or reductase functionality. Prostate tumours are considerably hypoxic as discussed in this thematic issue $^{[216]}$ and enzymes such as ALDHs are likely to be expressed differentially within the TME due to different pressures including hypoxic stress and types of cells such as MDR and CSCs.

The limited sensitivity of hypoxic tumours to radiotherapy may in part be related to $\mathrm{CSC}$ s residing in the hypoxic niche. Primary human PCa samples express both elevated levels of ALDH1A1+ and hypoxia inducible factor 1 alpha $(\mathrm{HIF}-1 \alpha)$, which have been linked to radioresistance ${ }^{[217,218]}$. A recent study $^{[219]}$ demonstrated that irradiation enriched the CSC population of DU145 and PC-3 cells. The irradiated cells were shown to possess elevated ALDH functional activity as well as DNA damage response activity, and in vivo the irradiated ALDH+ cells were shown to maintain their tumorigenic properties, suggesting these might be radioresistant in vivo. Furthermore, in primary human prostate tumours, IHC analysis revealed co-localisation of ALDH1A1 and HIF-1a expression, implying that a subset of ALDH+ cells resides in the hypoxic niche and emphasising the need to target these to effectively eradicate heterogeneous prostate tumours.

In other tumours, for example radiation resistant mesenchymal glioma, the SCs (MGSCs) possess elevated glycolytic activity and ALDH activity, in contrast to benign proneural SCs. Expression of ALDH1A3 was increased in clinical high-grade glioma compared with low-grade glioma or normal brain tissue ${ }^{[220]}$. Encouragingly, although the MGSCs were very aggressive in vitro and in vivo, the pan- 


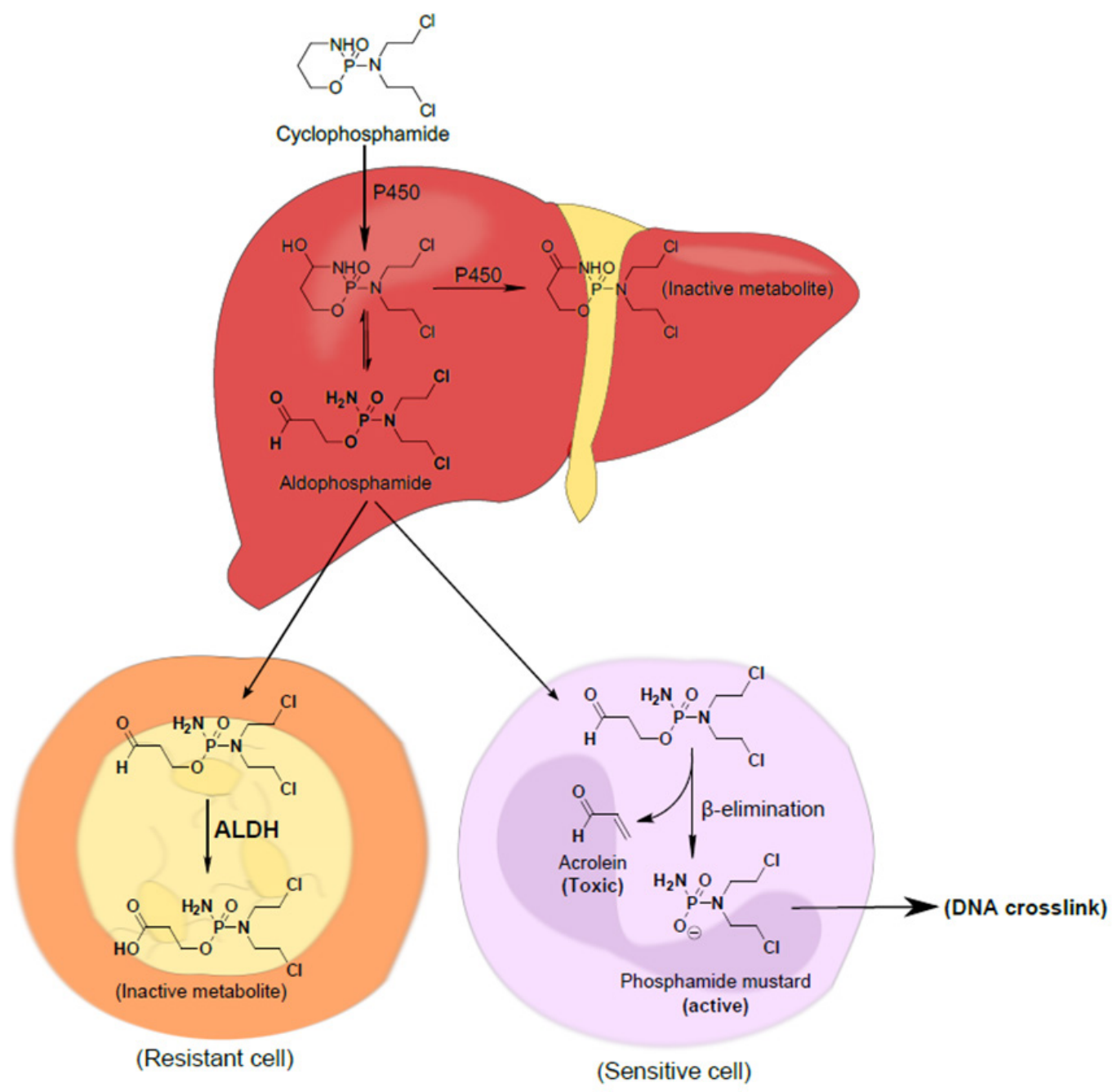

Figure 2: Cytochrome P450 (CYP) activation of cyclophosphamide (CPA). Initial hydroxylation of CPA in the liver by CYP isoforms leads to generation of aldophosphamide, an intermediate which is a substrate for aldehyde dehydrogenases (ALDHs) metabolism. If aldophosphamide enters circulation it is very likely to be detoxified in ALDH-expressing cells including cancer stem cells (CSCs), but not in cancer cells with low or absent ALDH expression

ALDH inhibitor DEAB significantly reduced cellular proliferation in vitro. This investigation suggested that two subtypes of MGSCs, harbouring distinct metabolic signaling pathways, constitute intratumoural glioma heterogeneity. ALDH1A3 was proposed to play an important role in the glycolysis pathway, via catalytic metabolism of acetaldehyde to acetate that is in turn linked to the tricarboxylic acid (TCA) cycle ${ }^{[220]}$. The glycolysis pathway is interesting because of the link to the TME and what is defined as the "Warburg effect". A recent study ${ }^{[221]}$ reported on the mitochondrial pyruvate carrier 1 (MPC1) gene in knockout studies using CRISPR/Cas9 technology in RM-1 murine PCa cells. The MPC1 gene knockout cells revealed a metabolism reprogramming to aerobic glycolysis with reduced ATP production, increase in cell migration and resistance to both chemo- and radiotherapy. In addition, the MPC1 knockout cells expressed significantly higher levels of the stemness markers Nanog, HIF-1a, Notch1, CD44 and ALDH.

The latter study provides an alternative route for therapeutic intervention, focussed on reprogramming glycolytic pathways. ALDHs such as the $1 \mathrm{~A} 3$ isoform could be a key player in such therapeutic intervention. However, as we ${ }^{[45]}$ and others ${ }^{[46,87,222]}$ have discussed previously, the expression of ALDHs in normal tissue expression remain a stumbling block towards a credible clinical therapy. However, advances in drug delivery technologies could in the future enable administration of an ALDH inhibitor, which is potently selective for a specific isoform. For example, a recent report ${ }^{[223]}$ indicate that the latter might be achieved in combination with radiotherapy, or as an option to sensitise heterogeneous prostate tumour responses to docetaxel. 


\section{CONCLUDING REMARKS}

The number of papers that report ALDH expression in the context of cancer is largely attributable to the use of the Aldefluor assay as a means to identify and isolate subpopulations with particularly stemness characteristics. However, selected ALDH isoforms are also emerging as critical players in chemoand radioresistance and a signature of tumour aggressiveness in conjunction with cells capable of migration, invasion and metastasis. Still, as is clear from this review of ALDH expression and function in PCa and other recent reviews ${ }^{[45,46,87,222]}$, the ever increasing number of publications that reveal inconsistent and sometimes contradictory information is not helpful in clarifying ALDHs as potential biomarkers of specific cancer types or CSC population; e.g., many early studies that reported on ALDHs, utilised antibodies that only stained for e.g. ALDH1 but were not selective for $1 \mathrm{~A} 1,1 \mathrm{~A} 2,1 \mathrm{~A} 3$, $1 \mathrm{~B} 1,1 \mathrm{~L} 1$ or $1 \mathrm{~L} 2$. Equally the Aldefluor assay is not isoform-selective and has contributed to inefficient validation of these enzymes. Furthermore, previous studies were carried out when the understanding of cancer cell subtypes, and the involvement of TME was limited, resulting in incomplete ALDH profiling. Bearing this in mind, currently emerging evidence in $P C a$ suggests the dominant isoforms are ALDH1A1, 1A2, 1A3, 3A1 and 7A1. The expression and function have been demonstrated using a number of different $2 \mathrm{D}$ and $3 \mathrm{D}$ cancer models as well as clinical samples. Further investigations of these isoforms are required in order to fully validate their potential as biomarkers or targets for therapeutic intervention. Such investigations should take better account on our choices of models as argued by Maitland in accompanying review ${ }^{[224]}$ in this thematic issue. As discussed in this review, ALDH enzymes also play a functional role in CSC populations, in the context of the TME. This synergy will be important in future studies to dissect whether ALDH expression leads to drug resistance via direct or indirect mechanisms. Underpinning the role of the RA signalling pathways, and the glycolytic biochemical pathways associated with the Warburg effect form part of both a regulatory network and a vicious cycle of tumour aggressiveness. The TME no doubt plays a critical role in exerting this selective pressure on ALDH expression and function, and hence should be more carefully considered in unravelling the cellular roles for specific ALDH isoforms. In this regard, use of siRNA, CRISPR and the development of highly specific small molecules to probe ALDH function will enable us more quickly ascertain the importance of specific ALDHs.

\section{DECLARATIONS}

\section{Acknowledgments}

We wish to acknowledge Prostate Cancer UK (RIA15ST2-022 \& PhD grant S12-027) for financial support and sponsorship, and Yaqeen Sawalha for producing figures for this manuscript.

\section{Author's contributions}

Manuscript writting and revision: Ibrahim AIM, Sadiq M, Frame FM, Maitland NJ, Pors K

\section{Availability of data and materials \\ Not applicable.}

\section{Financial support and sponsorship}

None.

\section{Conflicts of interest}

The authors declare there are no conflicts of interest.

\section{Ethical approval and consent to participate Not applicable.}

\section{Consent for publication}

Not applicable.

\section{Copyright}

(c) The Author(s) 2018.

\section{REFERENCES}

1. Ramalingam S, Ramamurthy VP, Njar VC. Dissecting major signaling pathways in prostate cancer development and progression: mechanisms and novel therapeutic targets. J Steroid Biochem Mol Biol 2017;166:16-27.

2. Loblaw DA, Virgo KS, Nam R, Somerfield MR, Ben-Josef E, Mendelson DS, Middleton R, Sharp SA, Smith TJ, Talcott J, Taplin M, Vogelzang NJ, Wade JL 3rd, Bennett CL, Scher HI. Initial hormonal management of androgen-sensitive metastatic, recurrent, or progressive prostate cancer: 2006 update of an American Society of Clinical Oncology practice guideline. J Clin Oncol 2007;25:1596-605.

3. Pienta KJ, Bradley D. Mechanisms underlying the development of androgen-independent prostate cancer. Clin Cancer Res 2006;12:1665-71

4. Vermeulen L, Melo FDSE, van der Heijden M, Cameron K, de Jong JH, Borovski T, Tuynman JB, Todaro M, Merz C, Rodermond H, Sprick MR, Kemper K, Richel DJ, Stassi G, Medema JP. Wnt activity defines colon cancer stem cells and is regulated by the microenvironment. Nat Cell Biol 2010;12:468-76.

5. Morrissey C, Vessella RL. The role of tumor microenvironment in prostate cancer bone metastasis. J Cell Biochem 2007;101:873-86.

6. Barron DA, Rowley DR. The reactive stroma microenvironment and prostate cancer progression. Endocr Relat Cancer 2012;19:R187- 
204.

7. Karlou M, Tzelepi V, Efstathiou E. Therapeutic targeting of the prostate cancer microenvironment. Nat Rev Urol 2010;7:494-509.

8. Zhu ML, Kyprianou N. Androgen receptor and growth factor signaling cross-talk in prostate cancer cells. Endocr Relat Cancer 2008;15:841-9.

9. Yauch RL, Gould SE, Scales SJ, Tang T, Tian H, Ahn CP, Marshall D, Fu L, Januario T, Kallop D, Nannini-Pepe M, Kotkow K, Marsters JC, Rubin LL, de Sauvage FJ. A paracrine requirement for hedgehog signalling in cancer. Nature 2008;455:406-10.

10. Grose R, Dickson C. Fibroblast growth factor signaling in tumorigenesis. Cytokine Growth Factor Rev 2005;16:179-86.

11. Nam S, Kim DW, Cheng JQ, Zhang SM, Lee JH, Buettner R, Mirosevich J, Lee FY, Jove R. Action of the Src family kinase inhibitor, dasatinib (BMS-354825), on human prostate cancer cells. Cancer Res 2005;65:9185-9.

12. Bhowmick NA, Chytil A, Plieth D, Gorska AE, Dumont N, Shappell S, Washington MK, Neilson EG, Moses HL. TGF-beta signaling in fibroblasts modulates the oncogenic potential of adjacent epithelia. Science 2004;303:848-51.

13. Goel HL, Li J, Kogan S, Languino LR. Integrins in prostate cancer progression. Endocr Relat Cancer 2008; 15:657-64.

14. Shou JY, Ross S, Koeppen H, de Sauvage FJ, Gao WQ. Dynamics of notch expression during murine prostate development and tumorigenesis. Cancer Res 2001;61:7291-7.

15. van den Hoogen C, van der Horst G, Cheung H, Buijs JT, Lippitt JM, Guzman-Ramirez N, Hamdy FC, Eaton CL, Thalmann GN, Cecchini MG, Pelger RC, van der Pluijm G. High aldehyde dehydrogenase activity identifies tumor-initiating and metastasis-initiating cells in human prostate cancer. Cancer Res 2010;70:5163-73.

16. Clarke MF, Dick JE, Dirks PB, Eaves CJ, Jamieson CH, Jones DL, Visvader J, Weissman IL, Wahl GM. Cancer stem cells--perspectives on current status and future directions: AACR Workshop on cancer stem cells. Cancer Res 2006;66:9339-44.

17. Zhang JW, Niu C, Ye L, Huang HY, He X, Tong WG, Ross J, Haug J, Johnson T, Feng JQ, Harris S, Wiedemann LM, Mishina Y, Li LH. Identification of the haematopoietic stem cell niche and control of the niche size. Nature 2003;425:836-41.

18. Suda T, Arai F, Hirao A. Hematopoietic stem cells and their niche. Trends Immunol 2005;26:426-33.

19. Borovski T, Melo FDE, Vermeulen L, Medema JP. Cancer stem cell niche: the place to be. Cancer Res 2011;71:634-9.

20. Yi SY, Hao YB, Nan KJ, Fan TL. Cancer stem cells niche: a target for novel cancer therapeutics. Cancer Treat Rev 2013;39:290-6.

21. Maitland NJ, Collins AT. Prostate cancer stem cells: a new target for therapy. J Clin Oncol 2008;26:2862-70.

22. Maitland NJ, Collins AT. Cancer stem cells - a therapeutic target? Curr Opin Mol Ther 2010;12:662-73.

23. Kozma E, Jayasekara PS, Squarcialupi L, Paoletta S, Moro S, Federico S, Spalluto G, Jacobson KA. Fluorescent ligands for adenosine receptors. Bioorg Med Chem Lett 2013;23:26-36.

24. Marchitti SA, Brocker C, Stagos D, Vasiliou V. Non-P450 aldehyde oxidizing enzymes: the aldehyde dehydrogenase superfamily. Expert Opin Drug Metab Toxicol 2008;4:697-720.

25. Vasiliou V, Nebert DW. Analysis and update of the human aldehyde dehydrogenase (ALDH) gene family. Hum Genomics 2005;2:138-43.

26. Sladek NE. Human aldehyde dehydrogenases: potential pathological, pharmacological, and toxicological impact. J Biochem Mol Toxicol 2003; 17:7-23.

27. Stewart MJ, Malek K, Crabb DW. Distribution of messenger
RNAs for aldehyde dehydrogenase 1, aldehyde dehydrogenase 2, and aldehyde dehydrogenase 5 in human tissues. J Investig Med 1996;44:42-6.

28. Yanagawa Y, Chen JC, Hsu LC, Yoshida A. The transcriptional regulation of human aldehyde dehydrogenase I gene. The structural and functional analysis of the promoter. $J$ Biol Chem 1995;270:17521-7.

29. Vasiliou V, Pappa A, Estey T. Role of human aldehyde dehydrogenases in endobiotic and xenobiotic metabolism. Drug Metab Rev 2004:36:279-99.

30. Alnouti Y, Klaassen CD. Tissue distribution, ontogeny, and regulation of aldehyde dehydrogenase (Aldh) enzymes mRNA by prototypical microsomal enzyme inducers in mice. Toxicol Sci 2008;101:51-64.

31. Black WJ, Stagos D, Marchitti SA, Nebert DW, Tipton KF, Bairoch A, Vasiliou V. Human aldehyde dehydrogenase genes: alternatively spliced transcriptional variants and their suggested nomenclature. Pharmacogenet Genomics 2009;19:893-902.

32. Koppaka V, Thompson DC, Chen Y, Ellermann M, Nicolaou KC, Juvonen RO, Petersen D, Deitrich RA, Hurley TD, Vasiliou V. Aldehyde dehydrogenase inhibitors: a comprehensive review of the pharmacology, mechanism of action, substrate specificity, and clinical application. Pharmacol Rev 2012;64:520-39.

33. Yokoyama A, Muramatsu T, Omori T, Yokoyama T, Matsushita S, Higuchi S, Maruyama K, Ishii H. Alcohol and aldehyde dehydrogenase gene polymorphisms and oropharyngolaryngeal, esophageal and stomach cancers in Japanese alcoholics. Carcinogenesis 2001;22:433-9.

34. Onenli-Mungan N, Yuksel B, Elkay M, Topaloglu AK, Baykal T, Ozer G. Type II hyperprolinemia: a case report. Turk $J$ Pediatr 2004;46:167-9.

35. Akaboshi S, Hogema BM, Novelletto A, Malaspina P, Salomons GS, Maropoulos GD, Jakobs C, Grompe M, Gibson KM. Mutational spectrum of the succinate semialdehyde dehydrogenase (ALDH5A1) gene and functional analysis of 27 novel disease-causing mutations in patients with SSADH deficiency. Hum Mutat 2003;22:442-50.

36. Mills PB, Struys E, Jakobs C, Plecko B, Baxter P, Baumgartner M, Willemsen MA, Omran H, Tacke U, Uhlenberg B, Weschke B, Clayton PT. Mutations in antiquitin in individuals with pyridoxinedependent seizures. Nat Med 2006;12:307-9.

37. Baumgartner MR, Hu CA, Almashanu S, Steel G, Obie C, Aral B, Rabier D, Kamoun P, Saudubray JM, Valle D. Hyperammonemia with reduced ornithine, citrulline, arginine and proline: a new inborn error caused by a mutation in the gene encoding delta(1)-pyrroline-5carboxylate synthase. Hum Mol Genet 2000;9:2853-8.

38. Enomoto N, Takase S, Takada N, Takada A. Alcoholic liver disease in heterozygotes of mutant and normal aldehyde dehydrogenase-2 genes. Hepatology 1991;13:1071-5.

39. Kamino K, Nagasaka K, Imagawa M, Yamamoto H, Yoneda H, Ueki A, Kitamura S, Namekata K, Miki T, Ohta S. Deficiency in mitochondrial aldehyde dehydrogenase increases the risk for lateonset Alzheimer's disease in the Japanese population. Biochem Biophys Res Commun 2000;273:192-6.

40. Lohberger B, Rinner B, Stuendl N, Absenger M, Liegl-Atzwanger B, Walzer SM, Windhager R, Leithner A. Aldehyde dehydrogenase 1, a potential marker for cancer stem cells in human sarcoma. PLoS One 2012;7:e43664.

41. Shimamura M, Nagayama Y, Matsuse M, Yamashita S, Mitsutake $\mathrm{N}$. Analysis of multiple markers for cancer stem-like cells in human thyroid carcinoma cell lines. Endocr J 2014;61:481-90.

42. Kunju LP, Cookingham C, Toy KA, Chen W, Sabel MS, Kleer CG 
EZH2 and ALDH-1 mark breast epithelium at risk for breast cancer development. Mod Pathol 2011;24:786-93.

43. Burgos-Ojeda D, Rueda BR, Buckanovich RJ. Ovarian cancer stem cell markers: prognostic and therapeutic implications. Cancer Lett 2012;322:1-7.

44. Chen Y, Orlicky DJ, Matsumoto A, Singh S, Thompson DC, Vasiliou V. Aldehyde dehydrogenase 1B1 (ALDH1B1) is a potential biomarker for human colon cancer. Biochem Biophys Res Commun 2011;405:173-9.

45. Pors K, Moreb JS. Aldehyde dehydrogenases in cancer: an opportunity for biomarker and drug development? Drug Discov Today 2014;19:1953-63.

46. Rodriguez-Torres M, Allan AL. Aldehyde dehydrogenase as a marker and functional mediator of metastasis in solid tumors. Clin Exp Metastasis 2016;33:97-113.

47. Tomita H, Tanaka K, Tanaka T, Hara A. Aldehyde dehydrogenase 1A1 in stem cells and cancer. Oncotarget 2016;7:11018-32.

48. Liu Y, Lv DL, Duan JJ, Xu SL, Zhang JF, Yang XJ, Zhang X, Cui YH, Bian XW, Yu SC. ALDH1A1 expression correlates with clinicopathologic features and poor prognosis of breast cancer patients: a systematic review and meta-analysis. $B M C$ Cancer 2014; $14: 444$

49. Alamgeer M, Ganju V, Szczepny A, Russell PA, Prodanovic Z, Kumar B, Wainer Z, Brown T, Schneider-Kolsky M, Conron M, Wright G, Watkins DN. The prognostic significance of aldehyde dehydrogenase 1A1 (ALDH1A1) and CD133 expression in early stage non-small cell lung cancer. Thorax 2013;68:1095-104.

50. Kahlert C, Bergmann F, Beck J, Welsch T, Mogler C, Herpel E, Dutta S, Niemietz T, Koch M, Weitz J. Low expression of aldehyde deyhdrogenase $1 \mathrm{~A} 1$ (ALDH1A1) is a prognostic marker for poor survival in pancreatic cancer. BMC Cancer 2011;11:275.

51. Kim H, Lapointe J, Kaygusuz G, Ong DE, Li CD, van de Rijn M, Brooks JD, Pollack JR. The retinoic acid synthesis gene ALDH1a2 is a candidate tumor suppressor in prostate cancer. Cancer Res 2005;65:8118-24.

52. Li T, Su Y, Mei YP, Leng QX, Leng BJ, Liu ZQ, Stass SA, Jiang F. ALDH1A1 is a marker for malignant prostate stem cells and predictor of prostate cancer patients' outcome. Lab Invest 2010;90:234-44.

53. Li XS, Xu Q, Fu XY, Luo WS. ALDH1A1 overexpression is associated with the progression and prognosis in gastric cancer. BMC Cancer 2014;14:705.

54. Touma SE, Perner S, Rubin MA, Nanus DM, Gudas LJ. Retinoid metabolism and ALDH1A2 (RALDH2) expression are altered in the transgenic adenocarcinoma mouse prostate model. Biochem Pharmacol 2009;78:1127-38.

55. Yang T, Rycaj K, Liu Z, Tang DG. Cancer stem cells: constantly evolving and functionally heterogeneous therapeutic targets. Cancer Res 2014;74:2922-7.

56. Leach DA, Buchanan G. Stromal androgen receptor in prostate cancer development and progression. Cancers (Basel) 2017;9: E10.

57. Cunha GR, Chung LW. Stromal-epithelial interactions--I. Induction of prostatic phenotype in urothelium of testicular feminized (Tfm/y) mice. J Steroid Biochem 1981;14:1317-24.

58. Donjacour AA, Cunha GR. The effect of androgen deprivation on branching morphogenesis in the mouse prostate. Dev Biol 1988;128:1-14.

59. Kunju LP, Cookingham C, Toy KA, Chen W, Sabel MS, Kleer CG. EZH2 and ALDH-1 mark breast epithelium at risk for breast cancer development. Modern Pathol 2011;24:786-93.

60. Orywal K, Jelski W, Werel T, Szmitkowski M. The diagnostic significance of serum alcohol dehydrogenase isoenzymes and aldehyde dehydrogenase activity in urinary bladder cancer patients. Anticancer Res 2017;37:3537-41.

61. Yan J, De Melo J, Cutz JC, Aziz T, Tang D. Aldehyde dehydrogenase $3 \mathrm{~A} 1$ associates with prostate tumorigenesis. $\mathrm{Br} J$ Cancer 2014;110:2593-603.

62. Le Magnen C, Bubendorf L, Rentsch CA, Mengus C, Gsponer J, Zellweger T, Rieken M, Thalmann GN, Cecchini MG, Germann M, Bachmann A, Wyler S, Heberer M, Spagnoli GC. Characterization and clinical relevance of ALDHbright populations in prostate cancer. Clin Cancer Res 2013;19:5361-71.

63. Doherty RE, Haywood-Small SL, Sisley K, Cross NA. Aldehyde dehydrogenase activity selects for the holoclone phenotype in prostate cancer cells. Biochem Biophys Res Commun 2011;414:801-7.

64. van den Hoogen C, van der Horst G, Cheung H, Buijs JT, Pelger $\mathrm{RC}$, van der Pluijm G. The aldehyde dehydrogenase enzyme 7A1 is functionally involved in prostate cancer bone metastasis. Clin Exp Metastasis 2011;28:615-25.

65. Wang S, Liang C, Bao M, Li X, Zhang L, Li S, Qin C, Shao P, Li J, Hua L, Wang Z. ALDH1A3 correlates with luminal phenotype in prostate cancer. Tumour Biol 2017;39:1010428317703652.

66. Casanova-Salas I, Masia E, Arminan A, Calatrava A, Mancarella C, Rubio-Briones J, Scotlandi K, Vicent MJ, Lopez-Guerrero JA. MiR-187 targets the androgen-regulated gene ALDH1A3 in prostate cancer. PLoS One 2015;10:e125576.

67. Trasino SE, Harrison EH, Wang TT. Androgen regulation of aldehyde dehydrogenase 1A3 (ALDH1A3) in the androgen-responsive human prostate cancer cell line LNCaP. Exp Biol Med (Maywood) 2007;232:762-71

68. Myers JS, von Lersner AK, Sang QX. Proteomic upregulation of fatty acid synthase and fatty acid binding protein 5 and identification of cancer- and race-specific pathway associations in human prostate cancer tissues. J Cancer 2016;7:1452-64.

69. Casanova-Salas I, Masia E, Arminan A, Calatrava A, Mancarella C, Rubio-Briones J, Scotlandi K, Vicent MJ, Lopez-Guerrero JA. MiR-187 targets the androgen-regulated gene ALDH1A3 in prostate cancer. PLoS One 2015;10:e0125576.

70. Lonergan PE, Tindall DJ. Androgen receptor signaling in prostate cancer development and progression. J Carcinog 2011;10:20.

71. Henshall SM, Quinn DI, Lee CS, Head DR, Golovsky D, Brenner PC, Delprado W, Stricker PD, Grygiel JJ, Sutherland RL. Altered expression of androgen receptor in the malignant epithelium and adjacent stroma is associated with early relapse in prostate cancer. Cancer Res 2001;61:423-7.

72. Ricciardelli C, Choong CS, Buchanan G, Vivekanandan S, Neufing P, Stahl J, Marshall VR, Horsfall DJ, Tilley WD. Androgen receptor levels in prostate cancer epithelial and peritumoral stromal cells identify non-organ confined disease. Prostate 2005;63:19-28.

73. Chen CD, Welsbie DS, Tran C, Baek SH, Chen R, Vessella R, Rosenfeld MG, Sawyers CL. Molecular determinants of resistance to antiandrogen therapy. Nat Med 2004;10:33-9.

74. Ruizeveld de Winter JA, Janssen PJ, Sleddens HM, VerleunMooijman MC, Trapman J, Brinkmann AO, Santerse AB, Schroder FH, van der Kwast TH. Androgen receptor status in localized and locally progressive hormone refractory human prostate cancer. $\mathrm{Am} \mathrm{J}$ Pathol 1994;144:735-46.

75. Chodak GW, Kranc DM, Puy LA, Takeda H, Johnson K, Chang C. Nuclear localization of androgen receptor in heterogeneous samples of normal, hyperplastic and neoplastic human prostate. J Urol 1992;147:798-803. 
76. Sadi MV, Walsh PC, Barrack ER. Immunohistochemical study of androgen receptors in metastatic prostate cancer. Comparison of receptor content and response to hormonal therapy. Cancer 1991;67:3057-64.

77. Feldman BJ, Feldman D. The development of androgen-independent prostate cancer. Nat Rev Cancer 2001;1:34-45.

78. Scher HI, Buchanan G, Gerald W, Butler LM, Tilley WD. Targeting the androgen receptor: improving outcomes for castration-resistant prostate cancer. Endocr Relat Cancer 2004;11:459-76.

79. Scher HI, Sawyers CL. Biology of progressive, castration-resistant prostate cancer: directed therapies targeting the androgen-receptor signaling axis. J Clin Oncol 2005;23:8253-61.

80. Ryan CJ, Smith A, Lal P, Satagopan J, Reuter V, Scardino P, Gerald W, Scher HI. Persistent prostate-specific antigen expression after neoadjuvant androgen depletion: an early predictor of relapse or incomplete androgen suppression. Urology 2006;68:834-9.

81. Buchanan G, Irvine RA, Coetzee GA, Tilley WD. Contribution of the androgen receptor to prostate cancer predisposition and progression. Cancer Metastasis Rev 2001;20:207-23.

82. Steinkamp MP, O’Mahony OA, Brogley M, Rehman H, Lapensee EW, Dhanasekaran S, Hofer MD, Kuefer R, Chinnaiyan A, Rubin MA, Pienta KJ, Robins DM. Treatment-dependent androgen receptor mutations in prostate cancer exploit multiple mechanisms to evade therapy. Cancer Res 2009;69:4434-42.

83. Locke JA, Guns ES, Lubik AA, Adomat HH, Hendy SC, Wood CA, Ettinger SL, Gleave ME, Nelson CC. Androgen levels increase by intratumoral de novo steroidogenesis during progression of castration-resistant prostate cancer. Cancer Res 2008;68:6407-15.

84. Heemers HV, Tindall DJ. Androgen receptor (AR) coregulators: a diversity of functions converging on and regulating the AR transcriptional complex. Endocr Rev 2007;28:778-808.

85. Zhu ML, Kyprianou N. Androgen receptor and growth factor signaling cross-talk in prostate cancer cells. Endocr Relat Cancer 2008;15:841-9.

86. Bergerat JP, Ceraline J. Pleiotropic functional properties of androgen receptor mutants in prostate cancer. Hum Mutat 2009;30:145-57.

87. Duan JJ, Cai J, Guo YF, Bian XW, Yu SC. ALDH1A3, a metabolic target for cancer diagnosis and therapy. Int J Cancer 2016;139:965-75.

88. van den Hoogen C, van der Horst G, Cheung H, Buijs JT, Pelger RCM, van der Pluijm G. The aldehyde dehydrogenase enzyme 7A1 is functionally involved in prostate cancer bone metastasis. Clin Exp Metastasis 2011;28:615-25.

89. Brocker C, Lassen N, Estey T, Pappa A, Cantore M, Orlova VV, Chavakis T, Kavanagh KL, Oppermann U, Vasiliou V. Aldehyde dehydrogenase 7A1 (ALDH7A1) is a novel enzyme involved in cellular defense against hyperosmotic stress. J Biol Chem 2010;285:18452-63.

90. Yang Z, Yang X, Wu Y, Wang J, Zhang Y, Xiong H, Jiang Y, Qin J. Clinical diagnosis, treatment, and ALDH7A1 mutations in pyridoxine-dependent epilepsy in three Chinese infants. PLoS One 2014;9:e92803.

91. Scharer G, Brocker C, Vasiliou V, Creadon-Swindell G, Gallagher RC, Spector E, Van Hove JL. The genotypic and phenotypic spectrum of pyridoxine-dependent epilepsy due to mutations in ALDH7A1. $J$ Inherit Metab Dis 2010;33:571-81.

92. Rose AE, Poliseno L, Wang J, Clark M, Pearlman A, Wang G, Vega YSdMEC, Medicherla R, Christos PJ, Shapiro R, Pavlick A, Darvishian F, Zavadil J, Polsky D, Hernando E, Ostrer H, Osman I. Integrative genomics identifies molecular alterations that challenge the linear model of melanoma progression. Cancer Res
2011;71:2561-71.

93. Saw YT, Yang J, Ng SK, Liu S, Singh S, Singh M, Welch WR, Tsuda H, Fong WP, Thompson D, Vasiliou V, Berkowitz RS, Ng SW. Characterization of aldehyde dehydrogenase isozymes in ovarian cancer tissues and sphere cultures. BMC Cancer 2012;12:329.

94. Giacalone NJ, Den RB, Eisenberg R, Chen H, Olson SJ, Massion PP, Carbone DP, Lu B. ALDH7A1 expression is associated with recurrence in patients with surgically resected non-small-cell lung carcinoma. Future Oncol 2013;9:737-45.

95. Milone MR, Pucci B, Bifulco K, Iannelli F, Lombardi R, Ciardiello C, Bruzzese F, Carriero MV, Budillon A. Proteomic analysis of zoledronic-acid resistant prostate cancer cells unveils novel pathways characterizing an invasive phenotype. Oncotarget 2015;6:5324-41.

96. Chandran UR, Ma CQ, Dhir R, Bisceglia M, Lyons-Weiler M, Liang WJ, Michalopoulos G, Becich M, Monzon FA. Gene expression profiles of prostate cancer reveal involvement of multiple molecular pathways in the metastatic process. BMC Cancer 2007;7:64.

97. Kim H, Lapointe J, Kaygusuz G, Ong DE, Li C, van de Rijn M, Brooks JD, Pollack JR. The retinoic acid synthesis gene ALDH1a2 is a candidate tumor suppressor in prostate cancer. Cancer Res 2005;65:8118-24.

98. Touma SE, Perner S, Rubin MA, Nanus DM, Gudas LJ. Retinoid metabolism and ALDH1A2 (RALDH2) expression are altered in the transgenic adenocarcinoma mouse prostate model. Biochem Pharmacol 2009;78:1127-38.

99. Shames DS, Girard L, Gao B, Sato M, Lewis CM, Shivapurkar N, Jiang A, Perou CM, Kim YH, Pollack JR, Fong KM, Lam CL, Wong M, Shyr Y, Nanda R, Olopade OI, Gerald W, Euhus DM, Shay JW, Gazdar AF, Minna JD. A genome-wide screen for promoter methylation in lung cancer identifies novel methylation markers for multiple malignancies. PLoS Med 2006;3:e486.

100. Collins AT, Berry PA, Hyde C, Stower MJ, Maitland NJ. Prospective identification of tumorigenic prostate cancer stem cells. Cancer Res 2005;65:10946-51.

101. Brown MD, Gilmore PE, Hart CA, Samuel JD, Ramani VA, George NJ, Clarke NW. Characterization of benign and malignant prostate epithelial Hoechst 33342 side populations. Prostate 2007;67:1384-96.

102. Hurt EM, Kawasaki BT, Klarmann GJ, Thomas SB, Farrar WL. CD44+ CD24(-) prostate cells are early cancer progenitor/stem cells that provide a model for patients with poor prognosis. $\mathrm{Br} J \mathrm{Cancer}$ 2008;98:756-65.

103. Goldstein AS, Huang J, Guo C, Garraway IP, Witte ON. Identification of a cell of origin for human prostate cancer. Science 2010;329:568-71.

104. Chen YJ, Chang JT, Liao CT, Wang HM, Yen TC, Chiu CC, Lu YC, Li HF, Cheng AJ. Head and neck cancer in the betel quid chewing area: recent advances in molecular carcinogenesis. Cancer Sci 2008;99:1507-14

105. Rajasekhar VK, Studer L, Gerald W, Socci ND, Scher HI. Tumourinitiating stem-like cells in human prostate cancer exhibit increased NF-kappaB signalling. Nat Commun 2011;2:162.

106. Maitland NJ, Frame FM, Polson ES, Lewis JL, Collins AT. Prostate cancer stem cells: do they have a basal or luminal phenotype? Horm Cancer 2011;2:47-61.

107. Maitland NJ, Collins AT. Cancer stem cells - a therapeutic target? Curr Opin Mol Ther 2010;12:662-73.

108. Szotek PP, Pieretti-Vanmarcke R, Masiakos PT, Dinulescu DM, Connolly D, Foster R, Dombkowski D, Preffer F, Maclaughlin DT, Donahoe PK. Ovarian cancer side population defines cells with stem cell-like characteristics and Mullerian inhibiting substance 
responsiveness. Proc Natl Acad Sci US A 2006;103:11154-9.

109. Ginestier C, Hur MH, Charafe-Jauffret E, Monville F, Dutcher J, Brown M, Jacquemier J, Viens P, Kleer CG, Liu S, Schott A, Hayes D, Birnbaum D, Wicha MS, Dontu G. ALDH1 is a marker of normal and malignant human mammary stem cells and a predictor of poor clinical outcome. Cell Stem Cell 2007;1:555-67.

110. Deng S, Yang X, Lassus H, Liang S, Kaur S, Ye Q, Li C, Wang LP, Roby KF, Orsulic S, Connolly DC, Zhang Y, Montone K, Butzow R, Coukos G, Zhang L. Distinct expression levels and patterns of stem cell marker, aldehyde dehydrogenase isoform 1 (ALDH1), in human epithelial cancers. PLoS One 2010;5:e10277.

111. Ucar D, Cogle CR, Zucali JR, Ostmark B, Scott EW, Zori R, Gray BA, Moreb JS. Aldehyde dehydrogenase activity as a functional marker for lung cancer. Chem Biol Interact 2009;178:48-55.

112. Huang EH, Hynes MJ, Zhang T, Ginestier C, Dontu G, Appelman H, Fields JZ, Wicha MS, Boman BM. Aldehyde dehydrogenase 1 is a marker for normal and malignant human colonic stem cells (SC) and tracks SC overpopulation during colon tumorigenesis. Cancer Res 2009;69:3382-9

113. Dembinski JL, Krauss S. Characterization and functional analysis of a slow cycling stem cell-like subpopulation in pancreas adenocarcinoma. Clin Exp Metastasis 2009;26:611-23.

114. van den Hoogen C, van der Horst G, Cheung H, Buijs JT, Lippitt JM, Guzman-Ramirez N, Hamdy FC, Eaton CL, Thalmann GN, Cecchini MG, Pelger RC, van der Pluijm G. High aldehyde dehydrogenase activity identifies tumor-initiating and metastasis-initiating cells in human prostate cancer. Cancer Res 2010;70:5163-73.

115. Birnie R, Bryce SD, Roome C, Dussupt V, Droop A, Lang SH, Berry PA, Hyde CF, Lewis JL, Stower MJ, Maitland NJ, Collins AT. Gene expression profiling of human prostate cancer stem cells reveals a pro-inflammatory phenotype and the importance of extracellular matrix interactions. Genome Biol 2008;9:R83.

116. Ma S, Chan KW, Lee TK, Tang KH, Wo JY, Zheng BJ, Guan XY. Aldehyde dehydrogenase discriminates the CD133 liver cancer stem cell populations. Mol Cancer Res 2008;6:1146-53.

117. Cheung AM, Wan TS, Leung JC, Chan LY, Huang H, Kwong YL, Liang R, Leung AY. Aldehyde dehydrogenase activity in leukemic blasts defines a subgroup of acute myeloid leukemia with adverse prognosis and superior NOD/SCID engrafting potential. Leukemia 2007;21:1423-30.

118. Yan J, De Melo J, Cutz JC, Aziz T, Tang D. Aldehyde dehydrogenase 3A1 associates with prostate tumorigenesis. Br J Cancer 2014;110:2593603.

119. Metzler MA, Sandell LL. Enzymatic metabolism of vitamin A in developing vertebrate embryos. Nutrients 2016;8:E812.

120. Canete A, Cano E, Munoz-Chapuli R, Carmona R. Role of vitamin $\mathrm{A} /$ retinoic acid in regulation of embryonic and adult hematopoiesis. Nutrients 2017;9:E159.

121. Czarnewski P, Das S, Parigi SM, Villablanca EJ. Retinoic acid and its role in modulating intestinal innate immunity. Nutrients 2017;9:E68.

122. Bono MR, Tejon G, Flores-Santibanez F, Fernandez D, Rosemblatt M, Sauma D. Retinoic acid as a modulator of T cell immunity. Nutrients 2016;8:E349.

123. Busada JT, Geyer CB. The role of retinoic acid (RA) in spermatogonial differentiation. Biol Reprod 2016;94:10.

124. Stevison F, Jing J, Tripathy S, Isoherranen N. Role of retinoic acidmetabolizing cytochrome P450s, CYP26, in inflammation and cancer. Adv Pharmacol 2015;74:373-412.

125. Doldo E, Costanza G, Agostinelli S, Tarquini C, Ferlosio A, Arcuri G, Passeri D, Scioli MG, Orlandi A. Vitamin A, cancer treatment and prevention: the new role of cellular retinol binding proteins. Biomed Res Int 2015;2015:624627.

126. Schenk T, Stengel S, Zelent A. Unlocking the potential of retinoic acid in anticancer therapy. Br J Cancer 2014;111:2039-45.

127. Napoli JL. Retinol metabolism in LLC-PK1 Cells. Characterization of retinoic acid synthesis by an established mammalian cell line. $J$ Biol Chem 1986;261:13592-7.

128. Wang C, Kane MA, Napoli JL. Multiple retinol and retina dehydrogenases catalyze all-trans-retinoic acid biosynthesis in astrocytes. J Biol Chem 2011;286:6542-53.

129. Pasquali D, Thaller C, Eichele G. Abnormal level of retinoic acid in prostate cancer tissues. J Clin Endocrinol Metab 1996;81:2186-91.

130. Mic FA, Haselbeck RJ, Cuenca AE, Duester G. Novel retinoic acid generating activities in the neural tube and heart identified by conditional rescue of Raldh 2 null mutant mice. Development 2002;129:2271-82.

131. Duester G. Involvement of alcohol dehydrogenase, short-chain dehydrogenase/reductase, aldehyde dehydrogenase, and cytochrome $\mathrm{P} 450$ in the control of retinoid signaling by activation of retinoic acid synthesis. Biochemistry 1996;35:12221-7.

132. Duester G. Retinoic acid synthesis and signaling during early organogenesis. Cell 2008;134:921-31.

133. Sima A, Parisotto M, Mader S, Bhat PV. Kinetic characterization of recombinant mouse retinal dehydrogenase types 3 and 4 for retinal substrates. Biochim Biophys Acta 2009;1790:1660-4.

134. Duester G, Mic FA, Molotkov A. Cytosolic retinoid dehydrogenases govern ubiquitous metabolism of retinol to retinaldehyde followed by tissue-specific metabolism to retinoic acid. Chem Biol Interact 2003;143-144:201-10.

135. Zhao D, McCaffery P, Ivins KJ, Neve RL, Hogan P, Chin WW, Drager UC. Molecular identification of a major retinoic-acidsynthesizing enzyme, a retinaldehyde-specific dehydrogenase. Eur $J$ Biochem 1996;240:15-22.

136. Appel B, Eisen JS. Retinoids run rampant: multiple roles during spinal cord and motor neuron development. Neuron 2003;40:461-4.

137. Elizondo G, Medina-Diaz IM, Cruz R, Gonzalez FJ, Vega L. Retinoic acid modulates retinaldehyde dehydrogenase 1 gene expression through the induction of GADD153-C/EBPbeta interaction. Biochem Pharmacol 2009;77:248-57

138. Delva L, Bastie JN, Rochette-Egly C, Kraiba R, Balitrand N, Despouy G, Chambon P, Chomienne C. Physical and functional interactions between cellular retinoic acid binding protein II and the retinoic acid-dependent nuclear complex. Mol Cell Biol 1999; $19: 7158-67$

139. Despouy G, Bastie JN, Deshaies S, Balitrand N, Mazharian A, RochetteEgly C, Chomienne C, Delva L. Cyclin D3 is a cofactor of retinoic acid receptors, modulating their activity in the presence of cellular retinoic acid-binding protein II. J Biol Chem 2003;278:6355-62.

140. Egea PF, Rochel N, Birck C, Vachette P, Timmins PA, Moras D. Effects of ligand binding on the association properties and conformation in solution of retinoic acid receptors RXR and RAR. $J$ Mol Biol 2001;307:557-76.

141. Glass CK, Rosenfeld MG. The coregulator exchange in transcriptional functions of nuclear receptors. Genes Dev 2000;14:121-41.

142. McKenna NJ, O’Malley BW. Combinatorial control of gene expression by nuclear receptors and coregulators. Cell 2002;108:465-74.

143. Zhang Y, Reinberg D. Transcription regulation by histone methylation: interplay between different covalent modifications of the core histone tails. Genes Dev 2001;15:2343-60.

144. Woychik NA, Hampsey M. The RNA polymerase II machinery 
structure illuminates function. Cell 2002;108:453-63.

145. Dilworth FJ, Chambon P. Nuclear receptors coordinate the activities of chromatin remodeling complexes and coactivators to facilitate initiation of transcription. Oncogene 2001;20:3047-54.

146. Tsagozis P, Augsten M, Pisa P. All trans-retinoic acid abrogates the pro-tumorigenic phenotype of prostate cancer tumor-associated macrophages. Int Immunopharmacol 2014;23:8-13.

147. Fontanelli BA, Chuffa LG, Teixeira GR, Amorim JP, Mendes LO, Pinheiro PF, Kurokawa CS, Pereira S, Favaro WJ, Martins OA, Mello Junior W, Martinez M, Junior AR, Martinez FE. Chronic ethanol consumption alters all-trans-retinoic acid concentration and expression of their receptors on the prostate: a possible link between alcoholism and prostate damage. Alcohol Clin Exp Res 2013;37:49-56.

148. Hammond LA, Van Krinks CH, Durham J, Tomkins SE, Burnett RD, Jones EL, Chandraratna RA, Brown G. Antagonists of retinoic acid receptors (RARs) are potent growth inhibitors of prostate carcinoma cells. Br J Cancer 2001;85:453-62.

149. Aboseif SR, Dahiya R, Narayan P, Cunha GR. Effect of retinoic acid on prostatic development. Prostate 1997;31:161-7.

150. Nelson CH, Buttrick BR, Isoherranen N. Therapeutic potential of the inhibition of the retinoic acid hydroxylases CYP26A1 and CYP26B1 by xenobiotics. Curr Top Med Chem 2013;13:1402-28.

151. Sosa MS, Parikh F, Maia AG, Estrada Y, Bosch A, Bragado P, Ekpin E, George A, Zheng Y, Lam HM, Morrissey C, Chung CY, Farias EF, Bernstein E, Aguirre-Ghiso JA. NR2F1 controls tumour cell dormancy via SOX9- and RARbeta-driven quiescence programmes. Nat Commun 2015;6:6170.

152. Roy A, Ramalinga M, Kim OJ, Chijioke J, Lynch S, Byers S, Kumar D. Multiple roles of RARRES1 in prostate cancer: autophagy induction and angiogenesis inhibition. PLoS One 2017;12:e0180344.

153. Oldridge EE, Walker HF, Stower MJ, Simms MS, Mann VM, Collins AT, Pellacani D, Maitland NJ. Retinoic acid represses invasion and stem cell phenotype by induction of the metastasis suppressors RARRES1 and LXN. Oncogenesis 2013;2:e45.

154. Trump DL, Smith DC, Stiff D, Adedoyin A, Day R, Bahnson RR, Hofacker J, Branch RA. A phase II trial of all-trans-retinoic acid in hormone-refractory prostate cancer: a clinical trial with detailed pharmacokinetic analysis. Cancer Chemother Pharmacol 1997;39:349-56.

155. Kelly WK, Osman I, Reuter VE, Curley T, Heston WD, Nanus DM, Scher HI. The development of biologic end points in patients treated with differentiation agents: an experience of retinoids in prostate cancer. Clin Cancer Res 2000;6:838-46.

156. Nehme A, Varadarajan P, Sellakumar G, Gerhold M, Niedner H, Zhang Q, Lin X, Christen RD. Modulation of docetaxel-induced apoptosis and cell cycle arrest by all- trans retinoic acid in prostate cancer cells. Br J Cancer 2001;84:1571-6.

157. Qian DZ, Ren M, Wei Y, Wang X, van de Geijn F, Rasmussen C, Nakanishi O, Sacchi N, Pili R. In vivo imaging of retinoic acid receptor beta 2 transcriptional activation by the histone deacetylase inhibitor MS-275 in retinoid-resistant prostate cancer cells. Prostate 2005;64:20-8.

158. Tang XH, Gudas LJ. Retinoids, retinoic acid receptors, and cancer. Annu Rev Pathol 2011;6:345-64.

159. Marcato P, Dean CA, Liu RZ, Coyle KM, Bydoun M, Wallace M, Clements D, Turner C, Mathenge EG, Gujar SA, Giacomantonio CA, Mackey JR, Godbout R, Lee PW. Aldehyde dehydrogenase 1A3 influences breast cancer progression via differential retinoic acid signaling. Mol Oncol 2015;9:17-31.

160. Koenig U, Amatschek S, Mildner M, Eckhart L, Tschachler E.
Aldehyde dehydrogenase $1 \mathrm{~A} 3$ is transcriptionally activated by alltrans-retinoic acid in human epidermal keratinocytes. Biochem Biophys Res Commun 2010;400:207-11.

161. Sullivan KE, Cerione RA, Wilson KF. ALDH1A3 in CSCs. Aging (Albany NY) 2017;9:1351-2.

162. Sullivan KE, Rojas K, Cerione RA, Nakano I, Wilson KF. The stem cell/cancer stem cell marker ALDH1A3 regulates the expression of the survival factor tissue transglutaminase, in mesenchymal glioma stem cells. Oncotarget 2017;8:22325-43.

163. Li Y, Wang L, Ai W, He N, Zhang L, Du J, Wang Y, Mao X, Ren J, $\mathrm{Xu}$ D, Zhou B, Li R, Mai L. Regulation of retinoic acid synthetic enzymes by WT1 and HDAC inhibitors in 293 cells. Int J Mol Med 2017;40:661-72.

164. Blum R, Gupta R, Burger PE, Ontiveros CS, Salm SN, Xiong X, Kamb A, Wesche H, Marshall L, Cutler G, Wang X, Zavadil J, Moscatelli D, Wilson EL. Molecular signatures of prostate stem cells reveal novel signaling pathways and provide insights into prostate cancer. PLoS One 2009; 4:e5722.

165. Polyak K, Weinberg RA. Transitions between epithelial and mesenchymal states: acquisition of malignant and stem cell traits. Nat Rev Cancer 2009;9:265-73.

166. Thiery JP. Epithelial-mesenchymal transitions in tumour progression. Nat Rev Cancer 2002;2:442-54.

167. Yang J, Weinberg RA. Epithelial-mesenchymal transition: at the crossroads of development and tumor metastasis. Dev Cell 2008; $14: 818-29$.

168. Tsuji T, Ibaragi S, Hu GF. Epithelial-mesenchymal transition and cell cooperativity in metastasis. Cancer Res 2009;69:7135-9.

169. Mol AJ, Geldof AA, Meijer GA, van der Poel HG, van Moorselaar RJ. New experimental markers for early detection of high-risk prostate cancer: role of cell-cell adhesion and cell migration. $J$ Cancer Res Clin Oncol 2007;133:687-95.

170. Jin JK, Dayyani F, Gallick GE. Steps in prostate cancer progression that lead to bone metastasis. Int J Cancer 2011;128:2545-61.

171. Gravdal K, Halvorsen OJ, Haukaas SA, Akslen LA. A switch from E-cadherin to $\mathrm{N}$-cadherin expression indicates epithelial to mesenchymal transition and is of strong and independent importance for the progress of prostate cancer. Clin Cancer Res 2007;13:7003-11.

172. Umbas R, Schalken JA, Aalders TW, Carter BS, Karthaus HF, Schaafsma HE, Debruyne FM, Isaacs WB. Expression of the cellular adhesion molecule E-cadherin is reduced or absent in high-grade prostate cancer. Cancer Res 1992;52:5104-9.

173. Umbas R, Isaacs WB, Bringuier PP, Schaafsma HE, Karthaus HF, Oosterhof GO, Debruyne FM, Schalken JA. Decreased E-cadherin expression is associated with poor prognosis in patients with prostate cancer. Cancer Res 1994;54:3929-33.

174. Jaggi M, Johansson SL, Baker JJ, Smith LM, Galich A, Balaji KC. Aberrant expression of E-cadherin and beta-catenin in human prostate cancer. Urol Oncol 2005;23:402-6.

175. Saha B, Arase A, Imam SS, Tsao-Wei D, Naritoku WY, Groshen $\mathrm{S}$, Jones LW, Imam SA. Overexpression of E-cadherin and betacatenin proteins in metastatic prostate cancer cells in bone. Prostate 2008;68:78-84.

176. Verras M, Sun ZJ. Roles and regulation of Wnt signaling and betacatenin in prostate cancer. Cancer Letters 2006;237:22-32.

177. Gupta S, Iljin K, Sara H, Mpindi JP, Mirtti T, Vainio P, Rantala J, Alanen K, Nees M, Kallioniemi O. FZD4 as a Mediator of ERG oncogene-induced WNT signaling and epithelial-to-mesenchymal transition in human prostate cancer cells. Cancer Res 2010;70:6735-45. 
178. Cojoc M, Peitzsch C, Kurth I, Trautmann F, Kunz-Schughart LA, Telegeev GD, Stakhovsky EA, Walker JR, Simin K, Lyle S, Fuessel S, Erdmann K, Wirth MP, Krause M, Baumann M, Dubrovska A. Aldehyde dehydrogenase is regulated by beta-catenin/TCF and promotes radioresistance in prostate cancer progenitor cells. Cancer Res 2015;75:1482-94.

179. Condello S, Morgan CA, Nagdas S, Cao L, Turek J, Hurley TD, Matei D. beta-Catenin-regulated ALDH1A1 is a target in ovarian cancer spheroids. Oncogene 2015;34:2297-308.

180. Wikstrom P, Stattin P, Franck-Lissbrant I, Damber JE, Bergh A. Transforming growth factor betal is associated with angiogenesis, metastasis, and poor clinical outcome in prostate cancer. Prostate 1998;37:19-29.

181. Hellsten R, Johansson M, Dahlman A, Sterner O, Bjartell A. Galiellalactone inhibits stem cell-like ALDH-positive prostate cancer cells. PLoS One 2011;6:e22118.

182. Kroon P, Berry PA, Stower MJ, Rodrigues G, Mann VM, Simms M, Bhasin D, Chettiar S, Li C, Li PK, Maitland NJ, Collins AT. JAKSTAT blockade inhibits tumor initiation and clonogenic recovery of prostate cancer stem-like cells. Cancer Res 2013;73:5288-98.

183. Tanei T, Morimoto K, Shimazu K, Kim SJ, Tanji Y, Taguchi T, Tamaki Y, Noguchi S. Association of breast cancer stem cells identified by aldehyde dehydrogenase 1 expression with resistance to sequential Paclitaxel and epirubicin-based chemotherapy for breast cancers. Clin Cancer Res 2009;15:4234-41.

184. Sladek NE. Aldehyde dehydrogenase-mediated cellular relative insensitivity to the oxazaphosphorines. Curr Pharm Des 1999;5:607-25.

185. Moreb JS, Schweder M, Gray B, Zucali J, Zori R. In vitro selection for K562 cells with higher retrovirally mediated copy number of aldehyde dehydrogenase class-1 and higher resistance to 4-hydroperoxycyclophosphamide. Hum Gene Ther 1998;9:611-9.

186. Wulf GG, Wang RY, Kuehnle I, Weidner D, Marini F, Brenner MK, Andreeff M, Goodell MA. A leukemic stem cell with intrinsic drug efflux capacity in acute myeloid leukemia. Blood 2001;98:1166-73.

187. Todaro M, Alea MP, Di Stefano AB, Cammareri P, Vermeulen L, Iovino F, Tripodo C, Russo A, Gulotta G, Medema JP, Stassi G. Colon cancer stem cells dictate tumor growth and resist cell death by production of interleukin-4. Cell Stem Cell 2007;1:389-402.

188. Ma S, Lee TK, Zheng BJ, Chan KW, Guan XY. CD133+ HCC cancer stem cells confer chemoresistance by preferential expression of the Akt/PKB survival pathway. Oncogene 2008;27:1749-58.

189. Hermann PC, Huber SL, Herrler T, Aicher A, Ellwart JW, Guba M, Bruns CJ, Heeschen C. Distinct populations of cancer stem cells determine tumor growth and metastatic activity in human pancreatic cancer. Cell Stem Cell 2007;1:313-23.

190. Croker AK, Allan AL. Inhibition of aldehyde dehydrogenase (ALDH) activity reduces chemotherapy and radiation resistance of stem-like ALDHhiCD44(+) human breast cancer cells. Breast Cancer Res Treat 2012;133:75-87.

191. Honoki K, Fujii H, Kubo A, Kido A, Mori T, Tanaka Y, Tsujiuchi T. Possible involvement of stem-like populations with elevated ALDH1 in sarcomas for chemotherapeutic drug resistance. Oncol Rep 2010;24:501-5.

192. Landen CN Jr, Goodman B, Katre AA, Steg AD, Nick AM, Stone RL, Miller LD, Mejia PV, Jennings NB, Gershenson DM, Bast RC Jr, Coleman RL, Lopez-Berestein G, Sood AK. Targeting aldehyde dehydrogenase cancer stem cells in ovarian cancer. Mol Cancer Ther 2010;9:3186-99.

193. Kawasoe M, Yamamoto Y, Okawa K, Funato T, Takeda M, Hara T, Tsurumi H, Moriwaki H, Arioka Y, Takemura M, Matsunami H,
Markey SP, Saito K. Acquired resistance of leukemic cells to AraC is associated with the upregulation of aldehyde dehydrogenase 1 family member A2. Exp Hematol 2013;41:597-603.e2.

194. Lee DH, Chung K, Song JA, Kim TH, Kang H, Huh JH, Jung SG, Ko JJ, An HJ. Proteomic identification of paclitaxel-resistance associated hnRNP A2 and GDI 2 proteins in human ovarian cancer cells. J Proteome Res 2010;9:5668-76.

195. Sun QL, Sha HF, Yang XH, Bao GL, Lu J, Xie YY. Comparative proteomic analysis of paclitaxel sensitive A549 lung adenocarcinoma cell line and its resistant counterpart A549-Taxol. J Cancer Res Clin Oncol 2011;137:521-32.

196. Barr MP, Gray SG, Hoffmann AC, Hilger RA, Thomale J, O'Flaherty JD, Fennell DA, Richard D, O’Leary JJ, O’Byrne KJ. Generation and characterisation of cisplatin-resistant non-small cell lung cancer cell lines displaying a stem-like signature. PLoS One 2013;8:e54193.

197. Sladek NE, Kollander R, Sreerama L, Kiang DT. Cellular levels of aldehyde dehydrogenases (ALDH1A1 and ALDH3A1) as predictors of therapeutic responses to cyclophosphamide-based chemotherapy of breast cancer: a retrospective study. Rational individualization of oxazaphosphorine-based cancer chemotherapeutic regimens. Cancer Chemother Pharmacol 2002;49:309-21.

198. Sreerama L, Sladek NE. Identification and characterization of a novel class 3 aldehyde dehydrogenase overexpressed in a human breast adenocarcinoma cell line exhibiting oxazaphosphorine-specific acquired resistance. Biochem Pharmacol 1993;45:2487-505.

199. Moreb JS, Mohuczy D, Ostmark B, Zucali JR. RNAi-mediated knockdown of aldehyde dehydrogenase class-1A1 and class-3A1 is specific and reveals that each contributes equally to the resistance against 4-hydroperoxycyclophosphamide. Cancer Chemother Pharmacol 2007;59:127-36.

200. Parajuli B, Fishel ML, Hurley TD. Selective ALDH3A1 inhibition by benzimidazole analogues increase mafosfamide sensitivity in cancer cells. J Med Chem 2014;57:449-61.

201. Marcato P, Dean CA, Pan D, Araslanova R, Gillis M, Joshi M, Helyer L, Pan L, Leidal A, Gujar S, Giacomantonio CA, Lee PW. Aldehyde dehydrogenase activity of breast cancer stem cells is primarily due to isoform ALDH1A3 and its expression is predictive of metastasis. Stem Cells 2011;29:32-45.

202. Bao S, Wu Q, McLendon RE, Hao Y, Shi Q, Hjelmeland AB, Dewhirst MW, Bigner DD, Rich JN. Glioma stem cells promote radioresistance by preferential activation of the DNA damage response. Nature 2006;444:756-60.

203. Gottesman MM, Fojo T, Bates SE. Multidrug resistance in cancer: role of ATP-dependent transporters. Nat Rev Cancer 2002;2:48-58.

204. Kondo T, Setoguchi T, Taga T. Persistence of a small subpopulation of cancer stem-like cells in the C6 glioma cell line. Proc Natl Acad Sci U S A 2004;101:781-6.

205. Smith PJ, Wiltshire M, Chappell SC, Cosentino L, Burns PA, Pors K, Errington RJ. Kinetic analysis of intracellular Hoechst 33342--DNA interactions by flow cytometry: misinterpretation of side population status? Cytometry A 2013;83:161-9.

206. Hilton J. Role of aldehyde dehydrogenase in cyclophosphamideresistant L1210 leukemia. Cancer Res 1984;44:5156-60.

207. Friedman HS, Colvin OM, Kaufmann SH, Ludeman SM, Bullock N, Bigner DD, Griffith OW. Cyclophosphamide resistance in medulloblastoma. Cancer Res 1992;52:5373-8.

208. Sreerama L, Sladek NE. Cellular levels of class 1 and class 3 aldehyde dehydrogenases and certain other drug-metabolizing enzymes in human breast malignancies. Clin Cancer Res 1997;3:1901-14.

209. Abdullah LN, Chow EK. Mechanisms of chemoresistance in cancer 
stem cells. Clin Transl Med 2013;2:3.

210. Rodriguez-Torres M, Allan AL. Aldehyde dehydrogenase as a marker and functional mediator of metastasis in solid tumors. Clin Exp Metastasis 2016;33:97-113.

211. Januchowski R, Wojtowicz K, Zabel M. The role of aldehyde dehydrogenase (ALDH) in cancer drug resistance. Biomed Pharmacother 2013;67:669-80.

212. Di C, Zhao Y. Multiple drug resistance due to resistance to stem cells and stem cell treatment progress in cancer (Review). Exp Ther Med 2015;9:289-93.

213. Chen YC, Chen YW, Hsu HS, Tseng LM, Huang PI, Lu KH, Chen DT, Tai LK, Yung MC, Chang SC, Ku HH, Chiou SH, Lo WL. Aldehyde dehydrogenase 1 is a putative marker for cancer stem cells in head and neck squamous cancer. Biochem Biophys Res Commun 2009;385:307-13.

214. Vinogradov S, Wei X. Cancer stem cells and drug resistance: the potential of nanomedicine. Nanomedicine (Lond) 2012;7:597-615

215. Harris AL. Hypoxia--a key regulatory factor in tumour growth. Nat Rev Cancer 2002;2:38-47.

216. McKenna DJ, Errington R, Pors K. Current challenges and opportunities in treating hypoxic prostate tumors. J Cancer Metastasis Treat 2018;4:11.

217. Movsas B, Chapman JD, Horwitz EM, Pinover WH, Greenberg RE, Hanlon AL, Iyer R, Hanks GE. Hypoxic regions exist in human prostate carcinoma. Urology 1999;53:11-8.

218. Stewart GD, Ross JA, McLaren DB, Parker CC, Habib FK, Riddick ACP. The relevance of a hypoxic tumour microenvironment in prostate cancer. BJU International 2010;105:8-13.

219. Cojoc M, Peitzsch C, Kurth I, Trautmann F, Kunz-Schughart LA, Telegeev GD, Stakhovsky EA, Walker JR, Simin K, Lyle S, Fuessel S, Erdmann K, Wirth MP, Krause M, Baumann M, Dubrovska A. Aldehyde dehydrogenase is regulated by beta-catenin/TCF and promotes radioresistance in prostate cancer progenitor cells. Cancer Res 2015;75:1482-94.

220. Mao P, Joshi K, Li J, Kim SH, Li P, Santana-Santos L, Luthra S, Chandran UR, Benos PV, Smith L, Wang M, Hu B, Cheng SY, Sobol RW, Nakano I. Mesenchymal glioma stem cells are maintained by activated glycolytic metabolism involving aldehyde dehydrogenase 1A3. Proc Natl Acad Sci US A 2013;110:8644-9.

221. Li X, Han G, Li X, Kan Q, Fan Z, Li Y, Ji Y, Zhao J, Zhang M, Grigalavicius M, Berge V, Goscinski MA, Nesland JM, Suo Z.
Mitochondrial pyruvate carrier function determines cell stemness and metabolic reprogramming in cancer cells. Oncotarget 2017;8:46363-80.

222. Clark DW, Palle K. Aldehyde dehydrogenases in cancer stem cells: potential as therapeutic targets. Ann Transl Med 2016;4:518.

223. Castro Nava A, Cojoc M, Peitzsch C, Cirillo G, Kurth I, Fuesse S, Erdmann K, Kunhardt D, Vittorio O, Hampel S, Dubrovska A. Development of novel radiochemotherapy approaches targeting prostate tumor progenitor cells using nanohybrids. Int $J$ Cancer 2015;137:2492-503.

224. Maitland NJ. Getting closer to prostate cancer in patients - what scientists should want from clinicians. J Cancer Metastasis Treat 2017;3:262-70.

225. Chen Y, Koppaka V, Thompson DC, Vasiliou V. Focus on molecules: ALDH1A1: from lens and corneal crystallin to stem cell marker. Exp Eye Res 2012;102:105-6.

226. Vasiliou V, Pappa A, Petersen DR. Role of aldehyde dehydrogenases in endogenous and xenobiotic metabolism. Chem Biol Interact 2000;129:1-19.

227. Stagos D, Chen Y, Brocker C, Donald E, Jackson BC, Orlicky DJ, Thompson DC, Vasiliou V. Aldehyde dehydrogenase 1B1: molecular cloning and characterization of a novel mitochondrial acetaldehydemetabolizing enzyme. Drug Metab Dispos 2010;38:1679-87.

228. Krupenko SA. FDH: an aldehyde dehydrogenase fusion enzyme in folate metabolism. Chem Biol Interact 2009;178:84-93.

229. Krupenko NI, Dubard ME, Strickland KC, Moxley KM, Oleinik NV, Krupenko SA. ALDH1L2 is the mitochondrial homolog of 10-formyltetrahydrofolate dehydrogenase. J Biol Chem 2010;285:23054-61.

230. Matsumoto A. Fundamental properties of aldehyde dehydrogenase 2 (ALDH2) and the importance of the ALDH2 polymorphism. Nihon Eiseigaku Zasshi 2016;71:55-68. (in Japanese)

231. Muzio G, Maggiora M, Paiuzzi E, Oraldi M, Canuto RA. Aldehyde dehydrogenases and cell proliferation. Free Radic Biol Med 2012;52:735-46.

232. Holmes RS. Biochemical genetics of opossum aldehyde dehydrogenase 3: evidence for three ALDH3A-like genes and an ALDH3B-like gene. Biochem Genet 2010;48:287-303.

233. Kim KJ, Pearl PL, Jensen K, Snead OC, Malaspina P, Jakobs C, Gibson KM. Succinic semialdehyde dehydrogenase: biochemicalmolecular-clinical disease mechanisms, redox regulation, and functional significance. Antioxid Redox Signal 2011;15:691-718. 